\title{
Almanca ve Türkçe Televizyon Reklamlarında Çok Katmanlılık: Ritter Sport ve Eti Reklamları Üzerine Karşıllaştırmalı Bir İnceleme*
}

\section{Multimodality in German and Turkish TV-Commercials: A Comparative Analysis of Ritter Sport and Eti Commercials}

\author{
İrem ATASOY' ${ }^{1}$
}

*Bu makale Almanca, Ingilizce ve Türkçe Reklam Filmlerinin Dilbilimsel Incelemesi başıklı doktora tezinden üretilmiştir.

${ }^{1}$ Araş. Gör. Dr., İstanbul Üniversitesi, Edebiyat Fakültesi, Alman Dili ve Edebiyat Anabilim Dalı, İstanbul, Türkiye

ORCID: I.A. 0000-0002-7661-2164

\section{Corresponding author:} İrem ATASOY,

İstanbul Üniversitesi, Edebiyat Fakültesi, Alman Dili ve Edebiyatı Anabilim Dalı, İstanbul, Türkiye

E-mail: irem.atasoy@istanbul.edu.tr

Submitted: 21.03 .2020

Accepted: 09.04.2020

Citation: Atasoy, I. (2020). Almanca ve Türkçe televizyon reklamlarında çok katmanlılık: Ritter Sport ve Eti Reklamları üzerine karșılaștırmalı bir inceleme. Alman Dili ve Edebiyatı Dergisi - Studien zur deutschen Sprache und Literatur, 43, 69-100. https://doi.org/10.26650/sds12020-0007 öz

Günümüzde gelişmekte olan teknolojinin de etkisiyle birlikte bildirişim biçimlerimizin çok katmanlı bir düzlemde gerçekleşmeye başlaması sonucunda ürettiğimiz ve karşılaştığımız metinler, tek katmanlı salt dilsel yapılar yerine, farklı gösterge sistemlerinden dil (yazılı ve/veya sözlü), görüntü (hareketli ve/veya hareketsiz), müzik (reklam melodisi ve/veya şarkı ve/veya enstrümental), ses (doğal ve/veya yapay) katmanlarını içeren ve anlam üretiminde bu katmanların tamamının farklı işlevler üstlenerek birbirini tamamladığı çok katmanlı yapılara dönüşmüştür. Bu yapılar dilbilim ve göstergebilimde çok katmanlı metinler olarak adlandırılmaktadır. Çok katmanlı metinler arasında bu iki bilimsel disiplinin en fazla incelediği türlerden biri televizyon reklamlardır. Televizyon reklamları hem dilbilim hem de göstergebilim alanında uygun dilsel, görsel ve işitsel göstergeleri kullanarak belli bir hedef kitleyi belirli bir ürün ya da hizmeti satın alması yönünde harekete geçirmeyi amaçlayan çok katmanlı metinler olarak tanımlanır. Bu çalışmanın amacı Almanca ve Türkçe televizyon reklamlarını çok katmanlı metin yaklaşımıyla karşılaştırmalı olarak inceleyerek bu iki farklı dildeki reklamların çok katmanlı yapıları arasındaki benzerliklerle farklılıkları ortaya çıkarmaktır. Bütünce olarak 2010-2016 yılları arasında yayınlanan Almanca ve Türkçe çikolata ve/veya çikolata içeren ürünlerin reklamları seçilmiştir. Seçilen reklamlar Alman Ritter Sport ve Türk Eti markalarına aittir. Çalışmada kullanılan ölçütler metindilbilim ve metin göstergebilim temelli çok katmanlı metin anlayışından yola çıkılarak belirlenmiştir. Yapılan çözümlemede bütüncedeki reklamlarda kullanılan dil, görüntü, müzik ve ses katmanları, alt katmanlarıyla birlikte ele alınarak bu katmanların arasındaki bağlantılar üzerinde durulmuştur.

Anahtar Kelimeler: Metindilbilim, metin göstergebilim, çok katmanlıık, çok katmanlı metin, televizyon reklamları

\section{ABSTRACT (ENGLISH)}

Today, with the advance of technology, our communication types have gained a multimodal characteristic. Therefore, nowadays texts are no longer seen as monomodal structures, which only include verbal information, but as multimodal 
structures, that combine different semiotic codes such as language (written and/or spoken), image (still and/or moving), music (jingle and/or song and/or instrumental) and sound (natural and/or artificial). These structures are called multimodal texts in linguistics and semiotics. Multimodal texts have a great potential for meaning making. In linguistics and semiotics, TV-Commercials are defined as multimodal texts, which use verbal, visual and auditory resources to convince a specific target group of buying a specific product or service. TV-Commercials are considered as one of the most analyzed multimodal text types in these two fields. The aim of this study is to analyze German and Turkish TV-Commercials with a multimodal oriented approach. This paper also presents the similarities and differences between the multimodal structures of the analyzed TVCommercials, respectively, multimodal texts, in two different languages. The corpus is comprised of TV-Commercials of chocolate and/or chocolate containing products which are produced by the German brand Ritter Sport and the Turkish brand Eti between 2010-2016. The analysis criteria have been defined moving towards a multimodal oriented method, that is based on text linguistics and text semiotics. The analysis focuses on the following modalities which are used in the selected corpus such as language, image, music and sound, as well as their submodalities and the intermodal relations between them.

Keywords: Text linguistics, text semiotics, mutlimodality, multimodal text, TV-Commercials

\section{EXTENDED ABSTRACT}

Today, with the advance of technology, our communication types have gained a multimodal characteristic. Therefore, nowadays texts are no longer seen as monomodal structures, which only include verbal messages, but as multimodal structures, that combine different semiotic codes such as language (written and/or spoken), image (still and/or moving), music (jingle and/or song and/or instrumental) and sound (natural and/ or artificial). These structures are called multimodal texts in linguistics and semiotics. Multimodal texts have a great potential for meaning making. In linguistics and semiotics, TV-Commercials are defined as multimodal texts, which use verbal, visual and auditory resources to convince a specific target group of buying a specific product or service. For this reason, they are considered as one of the most analyzed multimodal text types in these two fields.

The aim of this study is to analyze German and Turkish TV-Commercials with a multimodal oriented approach. This paper also presents the similarities and differences between the multimodal structures of the analyzed TV-Commercials, respectively, multimodal texts, in two different languages. The corpus is comprised of 20 TVCommercials of chocolate and/or chocolate containing products which are produced by the German brand Ritter Sport and the Turkish brand Eti between the years 2010 and 2016. For each language, ten different TV-Commercials of the mentioned brands are chosen randomly by considering the criteria that they contain the following modalities: language, image, music and sound. The analysis criteria have been defined moving 
towards a multimodal oriented theory, that is based on text linguistics and text semiotics. The analysis focuses on the following modalities which are used in the selected corpus such as language, image, music and sound, as well as their submodalities and the intermodal relations between them. All selected TV-Commercials which comprise the corpus of this study have been analyzed by using the mentioned criteria. Since a detailed analysis of each TV-Commercial is very comprehensive, only one data is chosen from each language to show an itemized examination.

The results of the analysis have been separately presented for each language, and comparatively interpreted by pointing out the similarities and differences between the analyzed TV-Commercials in German and Turkish languages. The detailed analysis of the modalities and intermodal relations of the researched TV-commercials has indicated that there are many similarities in the following modalities and submodalities; language - word types, image - visual items, color, light, camera range, and camera angle. It has been found that both German and Turkish TV-Commercials use similar verbal and visual modalities. The use of the brand names and the substantives "Schokolade (DE) / çikolata (TR)" as keywords is remarkable in all the selected TVCommercials in both languages. This can be related with the brands' values and advertised products. One of the most significant similarities between the analyzed TVCommercials is the connection between eating chocolate and being happy. To emphasize this relationship, similar visual and verbal modalities have been used synchronously, which are assisted by auditory modalities such as music and/or sound in the analyzed TV-Commercials. The analysis also detects that the intermodal connections between the modalities and submodalities in the selected TV-Commercials in the two languages are very coherent and compatible. This can be explained by the increasing impact of the globalization in advertising.

The results of the study have also shown that there are some differences in the use of the modalities music, sound, and the usage rate of the modalities in the examined German and Turkish TV-Commercials. In the analyzed German TV-Commercials, the same brand jingle called Colors of Life is played, whereas a different instrumental song is played in each Turkish TV-Commercial as background music. Besides, the intensive use of chocolate bar breaking sounds to indicate the quality of the advertised product is very significant in the Turkish TV-Commercials. The differences between the analyzed TVCommercials in the German and Turkish languages can be associated with the brands' values and types of the advertised products. 
According to the results of the multimodal analysis, there are more similarities than differences between the analyzed German and Turkish TV-Commercials. However, in terms of the use of the modalities, each language has an original characteristic. Based on the results of the multimodal oriented examination, this study demonstrates that due to the increasing globalization, TV-Commercials are becoming much more alike in their fundamental characteristics, even if they are created in different languages. 


\section{Giriş}

Son yıllarda modern teknolojideki gelişmelere koşut olarak bildirişim esnasında kullandığımız medya araçları çeşitlilik kazanmış ve bununla birlikte iletişim kurma biçimlerimiz de değişime uğramıştır. Günlük hayatımızın her anında fotoğraf, video, sesli/ görüntülü mesaj veya müzik gibi farklı katmanlardan ${ }^{1}$ yararlanabiliyor ve bunları bir arada kullanarak anlam üretebiliyor olmamız, iletişimi tek katmanlı yapıdan çok katmanlı bir yapıya dönüştürmüştür. Birden fazla katmanın bildirişim sırasında birbiriyle etkileşimli bir bütünlük içinde olma durumu, dilbilim ve göstergebilimde "çok katmanlılık" olarak tanımlanmaktadır (Van Leeuwen, 2005, s. 14). Bildirişimdeki bu çok katmanlılık, üretilen metinlere de yansıyarak geleneksel metin anlayışını değişime uğratmıştır. Bugün karşılaştığımız ve ürettiğimiz metinlerin çoğunda dilsel öğelerin yanı sıra, hareketli veya hareketsiz görüntüler, müzik ya da ses katmanları da bulunmaktadır. Bu katmanlardan en az ikisini içeren, anlamsal, işlevsel ve biçimsel tutarlılığa sahip konusal bütünlüğe sahip yapılar, "çok katmanlı metin" olarak adlandırıır (Stöckl, 2006, s. 17-23; 2011, s. 18-19; 2012, s. 245; Stöckl \& Schneider, 2011, s. 10-14; Wildfeuer, 2012, s. 279; Opiłowski, 2015, s. 93, Atasoy, 2019a, s. 8-9). Çok katmanlı metinler, içerdikleri katmanın türüne bağlı olarak kendi içinde basılı metinler (dil, görüntü, tipografi), işitsel metinler (dil, ses, müzik) ve görselişitsel metinler (dil, görüntü, müzik, ses) olarak üç temel gruba ayrılırlar (Klug \& Stöckl, 2015 , s. 247). Metindeki katman sayısı çoğaldıkça, daha karmaşık ve etkili anlamlar yaratma potansiyeli de artmaktadır. En fazla sayıda katmanın aynı anda bir arada bulunabildiği tek tür olan görsel-işitsel metinler, çok katmanlı metin incelemeleri için en geniş yelpazeyi sunarlar. Görsel-işitsel metinler arasında dilbilim ve göstergebilimin sıklıkla incelediği türlerden biri televizyon reklamlarıdır. Bilindiği üzere bu reklamların en büyük özelliği dilsel, görsel ve işitsel katmanların bir arada kullanılmasına olanak sağlayarak hem sesi hem de hareketli görüntüleri eş zamanlı olarak izleyicilere iletebilmeleridir. Bu bakımdan televizyon reklamları, çok katmanlı metin araştırmaları arasında en uygun inceleme nesneleri olarak görülmektedir (Stöckl, 2006, s. 15; 2007, s. 185; 2011, s. 21; Janich, 2010, s. 85; Stöckl \& Schneider, 2011, s. 18; Manca, 2012, s. 20-22). Buraya kadar yapılan açıklamalardan hareketle bu çalışmanın amacı Almanca ve Türkçe televizyon reklamlarını çok katmanlı metin yaklaşımıyla karşılaştırmalı olarak inceleyerek bu reklamların çok katmanlı yapıları arasındaki benzerliklerle farklılıkları ortaya çıkarmaktır.

1 Batı dillerindeki karşılığı "mode" olan bu kavram, bildirişim amacı taşıyan ve anlam üretmek için kullanılan kaynakların tümü olarak tanımlanmaktadır (Van Leeuwen, 2005, s. 160; Kress, 2010, s. 79).

2 Ingilizcede "multimodality", Almancada "Multimodalität" olarak olarak kullanılan bu kavramın Türkçe karşılığına yönelik çok modluluk, çok düzlemlilik gibi adlandırmalar da bulunmaktadır (Atasoy, 2019a, s. 8). 


\section{Dilbilim ve Göstergebilim Alanlarında Reklam Üzerine Yapılan Çalışmalar}

Reklamları bir metin türü olarak inceleyen dilbilim ve göstergebilim alanındaki çalışmalar 1960'ı yıllardan beri yürütülmektedir. Bu çalışmada Almanca ve Türkçe reklamlar karşılaştırmalı olarak incelendiği için reklam alanında yapılan araştırmalara ilişkin bilgiler aktarılırken yalnızca bu dillerdeki gıda sektörüne yönelik reklamların çözümlemelerini içeren bazı araştırmalardan elde edilen sonuçlara değinilecektir.

Polajnar'ın (2005) Almanca televizyon reklamlarında hedef kitleye seslenme biçimlerini ele aldığı Strategien der Adressierung in Kinderwerbespots: Zur Ansprache von Kindern und Eltern im Fernsehen başlıklı çalışmasının bütüncesi çocuklara yönelik ürünlerin tanıtıldığı oyuncak ve gıda sektörlerindeki televizyon reklamlarından oluşmaktadır. İncelemenin sonuç bölümünde ortaya koyulan en önemli bulgular şöyle sıralanabilir: Her iki sektördeki reklamlarda da sözlü dil kullanımı belirgin derecede yaygındır. Bununla birlikte oyuncak reklamlarında izleyicilere monolog biçiminde sözlü dilde iletiler üzerinden seslenilirken, gıda reklamlarında diyalog biçiminde sözlü dil kullanımının öne çıktığı belirlenmiştir (Polajnar, 2005, s. 202-204). Araştırmacı bu farklılığın nedenini incelediği reklamların yöneldiği hedef kitlelere dayandırmaktadır (Polajnar, 2005, s. 204205).

Mahovský'nin (2007) çalışması Almanca gıda reklamlardaki dil kullanımı üzerinedir. Bütüncesinde basılı, işitsel ve görsel-işitsel reklamlar bulunmaktadır. Araştırmacı yalnızca dil katmanına odaklanarak yaptığı dilbilimsel çözümleme sonucunda bütüncesindeki Almanca reklamlarda İngilizce sözcük kullanımının dikkat çekici boyutta olduğunu ortaya çıkarır ve bu sözcüklerin özellikle ürün adı veya ürün özelliklerini tanımlarken kullanıldıklarını belirtir. Mahovský incelediği Almanca reklamlarda İngilizcenin tercih edilmesinin nedenini, bu dildeki sözcüklerin Almanca karşılıklarına göre çok daha kısa olmaları ve tüketicilerin zihninde modernlik, gençlik, dinamiklik, uluslararasılık kavramlarını çağışstırması olarak açıklar (Mahovský, 2007, s. 51).

Rossi (2010) Almanca radyo reklamlarında müzik ve sesin dil kullanımı ile ikna stratejilerine ne ölçüde etki ettiğini sorgulamak amacıyla yaptığı çalışmasında Kinder markasına ait çikolata reklamlarını inceler. Radyo reklamlarında kullanılan katmanlararası ilişkilere odaklanan araştırmacı çalışmasının sonucunda şu bulgulara ulaşmıştır: Reklamlarda kullanılan müzik ve ritim ile konuşucuların ses yüksekliği ve tempoları 
tanıtılan ürüne göre değişkenlik göstermektedir (Rossi, 2010, s. 17-19). Rossi ayrıca, hedef kitle ve tanıtımı yapılan ürünün reklamdaki dil ve diğer katmanların kullanımına etki ettiğini belirtir (Rossi, 2010, s. 23-24).

Buggisch (2008) Nahrungsmittelwerbung und Kulturspezifik. Ein interkultureller Vergleich başlıklı çalışmasında Almanca, İngilizce ve İtalyanca gıda reklamlarını karşılaştırmalı olarak incelemiştir. Bütüncesindeki üç farklı dilden reklamları çok katmanlılık yaklaşımıyla çözümleyen araştırmacının Almanca reklamların incelemesinden elde ettiği sonuçlar şunlardır: Almanca gıda reklamlarda ve marka yerine ürün reklamları öne çıkmaktadır ve hedef kitleye Almancada nezaket anlamı taşıyan "Sie" adılıyla seslenilmektedir (Buggisch, 2008, s. 104-105). Çözümlenen Almanca reklamlarda sıklıkla İngilizce, Fransızca ve İtalyanca sözcükler kullanılmakta ve tanıtılan gıdalar ürün kullanıcısı konumunda çeşitli figürlerle birlikte gösterilmektedir (Buggisch, 2008, s. 106).

Manca (2012) "Geschlechterwissen in der TV-Werbung Fallanalyse eines deutschen Nahrungsmittel - Werbespots am Beispiel der Marke Knorr" adlı araştırmasında Almanca televizyon reklamlarında cinsiyet kurgulanışını incelemiştir. Bütüncesini gıda sektöründen belli bir markaya ait reklam filmleriyle sınırlayan araştırmacı, bu reklamlardaki görüntü katmanına odaklanır. Manca, araştırmasının sonuç bölümünde incelediği Almanca gıda reklamlarında kullanılan erkek, kadın ve çocuk figürlerin geleneksel stereotiplere uygun olarak kurgulandığını ve bu kurguyu pekiştirmek için belirli görsel öğelerden yararlanıldığını bulgulamıştır (Manca, 2012, s. 100-108).

Hoffmann (2014) Bierwerbung in Deutschland und Russland: Eine Analyse der Werbesprache başlıklı çalışmasında çeşitli bira markalarının tanıtıldığı Almanca ve Rusça televizyon reklamlarını karşılaştırmalı olarak incelemiştir. Çözümlemesinde yalnızca dil ve görüntü katmanlarına odaklanan Hoffmann'ın Almanca reklamların incelemesinden elde ettiği bazı önemli bulgular şöyle sıralanabilir: Çözümlenen Almanca reklamlarda tanıtılan biraların marka adları doğrudan belli bir aile veya coğrafi bölge adlarından oluşmaktadır ya da bu adları içermektedir. Reklamların tamamında ağırlıklı olarak doğa görüntülerine yer verilerek bira ve doğa arasında bağlantı kurulmaya çalışılmıştır (Hoffmann, 2014, s. 140-143).

Yılmaz (2004) çalışmasında Türkçe televizyon reklamlarındaki dil kullanımını incelemiştir. İnceleme nesnesi olarak seçtiği farklı sektörlere ait reklamlardaki dil 
katmanını metindilbilimin temelli ölçütlerle ele alan araştırmacının bu çalışmadan elde ettiği bulgulara göre Türkçe reklamlarda çok sayıda yabancı dilde sözcük bulunmaktadır. Bütünce olarak seçilen reklamlarda tanıtılan ürünleri piyasadaki benzerlerinden farklılaştırmak için çeşitli sıfatlardan yararlanıldığı gözlemlenmiştir. Gıda sektöründeki reklamlarda "tat" ve "lezzet" sözcüklerinin vurgulandığı belirlenmiştir (Yılmaz, 2004, s. 398399).

Kunt (2007) çalışmasında Almanca ve Türkçe reklamlardaki aile imgesini incelmek amacıyla farklı sektörlerden seçtiği reklamları sözdizimi, anlambilim ve göstergebilim açısından karşılaştırmalı olarak çözümler. Kunt'un gıda reklamlarının çözümlemesinden elde ettiği bulgular şöyledir (Kunt, 2007, s. 162-204): Almanca ve Türkçe gıda reklamlarında "Geschmack/lezzet", "natürlich/doğal", "Natur/doğa" sözcükleri öne çıkmaktadır. Almanca gıda reklamlarda İtalyanca sözcüklere yer verildiği ve Türkçe gıda reklamlarında yabancı dilde sözcüklere rastlanmadığı belirlenmiştir. Tanıtılan ürünler her iki dildeki gıda reklamlarında da ürün kullanıcısı konumda olan figürlerle bir arada gösterilmektedir.

Atasoy (2019b) Almanca, İtalyanca ve İspanyolca televizyon reklamlarını çok katmanlı metin yaklaşımıyla karşılaştırmalı olarak incelediği çalışmasında Knorr markası tarafından üretilen çorbaların tanıtıldığı reklamları çözümler. Çözümlemesinden elde ettiği sonuçlar şöyle sıralanabilir: incelenen reklamlarda dil katmanında her üç dilde de "Natur (ALM: doğa)", "naturale (iTA: doğal)" ve "naturales (iSP: doğal)" sözcükleri üzerinden ürünlerin doğallığına gönderim yapılmaktadır. Tanıtılan çorbalarla doğa arasındaki ilişkiyi pekiştirmek için tüm reklamlarda görüntü katmanında doğayı çağrıştıran renklerden ve çoğunlukla dalında ya da toprakta gösterilen çeşitli sebze ve sebze filizi görsellerinden yararlanılmıştır (Atasoy, 2019b, s. 323). Almanca ve İspanyolca reklamda hedef kitleye örtük biçimde marka adı üzerinden seslenilirken, İtalyanca reklamda açık biçimde nezaket bildiren "Lei" adılı kullanıldığı belirlenmiştir. Almanca ve İtalyanca reklamda erkekler çorba pişirip tek başlarına içerken, İspanyolca reklamda bir kadın ve bir erkek figür bulunmakta ve çorbayı kadın hazırlamaktadır. Atasoy, İspanyolca reklamda geleneksel kadın-erkek stereotiplerine bağlı kalınmasının nedenini reklamların yayınlandığı kültürlerle ilgili olabileceğini belirtir (Atasoy, 2019b, s. 324). 


\section{Bütünce}

Tablo 1: Bütünce

\begin{tabular}{|l|l|l|l|}
\hline \multicolumn{2}{|c|}{ Almanca Reklamlar } & \multicolumn{2}{c|}{ Türkçe Reklamlar } \\
\hline Reklam Aracı & Televizyon & Reklam Aracı & Televizyon \\
\hline Tarih Aralığı & $2010-2015$ & Tarih Aralığı & $2011-2016$ \\
\hline Reklam Süreleri & $10-24$ Saniye & Reklam Süreleri & $19-32$ Saniye \\
\hline Marka Adı & Ritter Sport & Marka Adı & Eti \\
\hline Ürün Türü & Çikolata & Ürün Türü & $\begin{array}{l}\text { Çikolata (bitter) \& çikolata } \\
\text { içeren ürünler }\end{array}$ \\
\hline Sektör & Gıda & Sektör & Gıda \\
\hline Hedef Kitle & $\begin{array}{l}\text { Çikolata tüketen yetişkinler } \\
\text { ve çocukar }\end{array}$ & Hedef Kitle & Çikolata tüketen yetişkinler \\
\hline
\end{tabular}

Bu çalışmanın bütüncesi farklı çikolata çeşitlerinin ve/veya yoğun çikolata içeren ürünlerin tanıtıldığı 2010-2016 yılları arasından yayınlanan Almanca ve Türkçe televizyon reklamlarından oluşmaktadır. Bütüncenin seçimi yapılırken ilk dikkate alınan ölçüt, reklamları veren çikolata üreticilerinin Alman ve Türk markaları olmalarıdır. Bu ölçüte göre araştırmada incelenecek iki farklı dili temsilen birer markanın belirlenmesine karar verilmiştir. Seçilen markalar Alman çikolata üreticisi Ritter Sport ile Türk çikolata üreticisi Eti'dir. Sonrasında bu markaların dil, görüntü, müzik ve/veya ses katmanlarını içeren televizyon reklamlarına yönelik internet ortamında kapsamlı bir tarama yapılmıştır. Yapılan tarama sonucunda yayın süreleri 10 ile 32 saniye arasında değişen 10 Almanca ve 10 Türkçe televizyon reklamı seçilmiştir. İnceleme nesnesi olarak belirlenen Ritter Sport markasına ait Almanca reklamlar 2010-2015 yılları arasında yayınlanmıştır. Bu reklamların tamamında içinde fındık, badem, portakal, çilek gibi farklı bileşenler içeren sütlü çikolata çeşitleri tanıtılmaktadır ve hedef kitlesi çikolata tüketen yetişkinler ile çocukları kapsamaktadır. Türkçe reklamlar ise 2011-2016 yılları arasında yayınlanmıştır ve ağırlıklı olarak bitter türünde çikolatalarla çok yoğun çikolata içeren ürünlerin tanıtımı üzerinedir. Türkçe reklamların yöneldiği hedef kitle yalnızca yetişkin bireylerden oluşmaktadır.

\section{Yöntem}

Bu çalışmada kullanılacak ölçütler, çok katmanlı metinleri incelemek için metindilibilim ve göstergebilim alanlarında kullanılan önemli çözümleme modellerinden yola çıkılarak geliştirilmiştir. Her metnin belli bir bildirişim amacıyla işlevsel, anlamsal ve biçimsel açıdan ortak özellikler taşıyan belirli dış ve iç etkenlere bağlı olarak üretildiği görüşünden hareketle Brinker'in (1997) geliştirdiği, metin dışı ve metin içi ölçütlerden oluşan iki 
aşamalı çözümleme modeli, aralarında çok katmanlı metin türleri üzerinde yapılan incelemelerin de bulunduğu çok sayıda metindilbilimsel ve metin göstergebilimsel araştırmaya kaynak olmuştur.

Reklamları metin göstergebilimsel açıdan çok katmanlılık anlayışıyla ele alan Stöckl (2004a; 2004b; 2007; 2012) çalışmalarında Brinker'in yaptığı ayrıma benzer şekilde çok katmanlı bir metin türü olarak reklamların kurgulanışında da belirleyici olan iç ve dış etkenler bulunduğundan bahseder ve onları büyük ölçekli yapı ile küçük ölçekli yapı olarak adlandırır (Karş. Brinker, 1997, s. 12-15). Büyük ölçekli yapıda işlev, marka, sektör, amaç, hedef kitle ile reklam aracı bulunurken, küçük ölçekli yapı reklamda kullanılan katmanlar ile alt katmanlardan oluşmaktadır.

Janich (2010) ise Werbesprache. Ein Arbeitsbuch adlı çalışmasında basılı türdeki reklamları incelerken Brinker'in metin dışı ve metin içi ölçütlerine bağlı kalmakla birlikte çok katmanlı metin araştırmalarına yönelik Brandt (1973) ve Hennecke (1999) tarafından geliştirilen diğer çözümleme modellerinden de yararlanarak yeni bir inceleme yöntemi geliştirmiştir (Janich, 2010, s. 267). Üç aşamadan oluşan bu yeni modelin ilk adımında metin dışı olarak adlandırılan etkenler, ikinci aşamada ise reklamın dilsel ve görsel yapısı ayrıntılı olarak analiz edilir. Son aşamada elde edilen tüm verilerin genel değerlendirmesi yapılmaktadır. Janich önerdiği bu çözümleme modelinin ikinci aşamasına bazı eklemeler yapıldığı takdirde basılı reklamların yanı sıra işitsel ve görsel-işitsel reklamlara da uyarlanabileceğini belirtir (2010, s. 265).

Kress'in (2010) toplumsal göstergebilim yaklaşımından yola çıkarak geliştirdiği çözümleme ölçütleri günümüzde çok katmanlılık ve çok katmanlı metinler üzerine yapılan araştırmalarının neredeyse tamamının temelini oluşturmaktadır. Kress çok katmanlı metinlerde her bir katmanın kendine özel bir işlevi olmakla birlikte anlam üretiminin katmanlararası $^{3}$ bir düzlemde gerçekleştiğini savunur (Kress, 2010, s. 54-67). Bu bakımdan çok katmanlı metin yaklaşımıyla reklamları incelerken katmanlar ile alt katmanların tamamının bir arada bütünlüklü olarak değerlendirilmesi ve metinde üstlendikleri işlevlerle birlikte katmanların birbirlerine nasıl bağlandıkları ve bu bağlantılardan hangi anlamların ortaya çıktığının da açıklanması gerekir (Kress, 2010, s. 163-167).

3 Katmanların birbirleriyle olan ilişkisi çok katmanlı metin yaklaşımında "katmanlararasılık" olarak adlandırılmaktadır (Van Leeuwen, 2005, s. 219-214; Stöckl, 2004b, s. 15-25; 2012, s. 251; Stöckl \& Schneider, 2011, s. 26). 
Buraya kadar söz edilen araştırmalardan yola çıkılarak bütüncedeki televizyon reklamlarını çözümlemek için aşağıdaki model oluşturulmuştur. Bu modelde yer alan çözümleme aşamaları Janich (2010), Stöckl (2011) ve Kress (2010) tarafından geliştirilen ölçütlerin birleştirilmiş versiyonudur (Atasoy, 2019a, s. 88).

Tablo 2: Televizyon Reklamları Çözümleme Modeli

\begin{tabular}{|c|c|c|}
\hline \multicolumn{3}{|c|}{ Televizyon Reklamları Çözümleme Modeli } \\
\hline Metin Dışı ÖIçütler & Reklam Aracı, Sekt & r, Reklamın Amacı, Hedef Kitle, İşlev, Marka \\
\hline \multirow{5}{*}{ Metin İçi Ölçütler } & Dil & $\begin{array}{l}\text { - Sözcük türleri (adlar, sıfatlar, eylemler, yabancı dildeki } \\
\text { sözcükler, neolojizmler) } \\
\text { - Tümce yapıları (bildirme tümceleri, emir tümceleri, soru } \\
\text { tümceleri, ünlem tümceleri, eksiltili tümceler) } \\
\text { - Hedef kitleye seslenme biçimleri (açık, örtük, benöyküsel, } \\
\text { senöyküsel, elöyküsel) }\end{array}$ \\
\hline & Görüntü & $\begin{array}{l}\text { - Renk } \\
\text { - Işık (normal, parlak, sönük) } \\
\text { - Çekim ölçeği (ayrıntı, yakın, göğüs, bel, diz, boy, uzak, } \\
\text { panoramik) } \\
\text { - Kamera perspektifi (normal bakış, alttan bakış, tepeden bakış) }\end{array}$ \\
\hline & Müzik & $\begin{array}{ll}\text { - } & \text { Ritim } \\
\text { - } & \text { Ton } \\
\text { - } & \text { Melodi } \\
\end{array}$ \\
\hline & Ses & $\begin{array}{l}\text { - Doğal sesler } \\
\text { - Yapay sesler } \\
\text { - Ses yüksekliği } \\
\text { - Ritim }\end{array}$ \\
\hline & $\begin{array}{c}\text { Katmanlararası } \\
\text { illişkiler }\end{array}$ & - Dil-Görüntü-Müzik-Ses bağlantıları \\
\hline
\end{tabular}

Bu çalışmada yararlanılan çözümleme modeli iki aşamadan oluşmaktadır. İlk aşamada metin dışı ölçütler olan reklam aracı, sektör, reklamın amacı, hedef kitle, işlev ve marka bulunmaktadır. İkinci aşama metin için ölçütleri kapsamaktadır. Bu ölçütler altında reklamın bileşenleri olarak kabul edilen dil, görüntü, müzik, ses katmanları ile alt katmanlarının ayrıntılı çözümlemesi ve katmanlararası bağlantıların değerlendirmesi yer almaktadır.

\section{Uygulama ve Bulgular}

Bu bölüm yukarıda ayrıntılı olarak açıklanan metindilbilimsel ve metin göstergebilimsel ölçütlerden yola çıkılarak geliştirilen çözümleme modelinin bütünceceki reklamlar üzerindeki uygulamasına ayrılmıştır. Araştırmada çözümlenen televizyon reklamlarının her birinin detaylı analizinin oldukça kapsamlı ve uzun olması nedeniyle çalışmanın uygulama kısmında, iki dili temsilen yalnızca bir Almanca ve bir Türkçe televizyon reklamının metin içi ölçütlere göre yapılan ayrıntılı çözümlemesine yer verilecektir. 


\section{1. Örnek Çözümleme: Ritter Sport Wintersorten Reklamı}

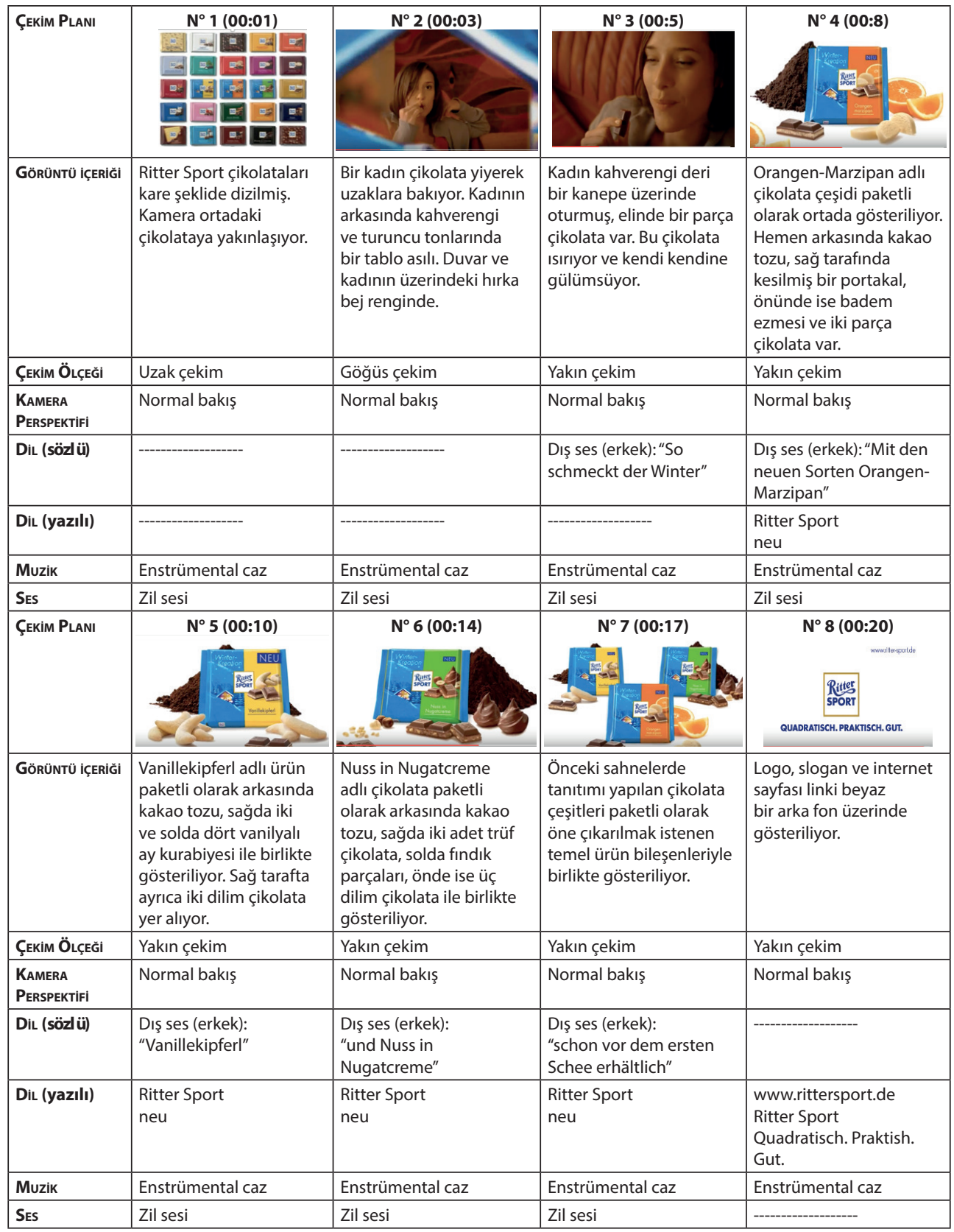


Örnek çözümleme için seçilen Almanca televizyon reklamında Ritter Sport markasının Wintersorten (kış çeşitleri) adlı çikolataları tanıtılmaktadır. Reklamın toplam süresi 20 saniyedir. İlk sahnede ilgili markanın farklı çikolata çeşitleri uzaktan bakıldığında kare biçimi oluşturacak şekilde dizilmiş olarak gösterilmektedir. Bir sonraki sahnede kahverengi deri kaplı bir kanepede tek başına oturan ve bej renkli bir hırka ile turuncu bir bluz giyen bir kadın çikolata ısırıp gülümsemektedir. Sonrasında kış çeşitleri olarak adlandırılan üç farklı çikolata çeşidi vurgulanmak istenen bazı bileşenleri ile bir arada vetilmektedir. Reklamın son sahnesi marka adı, slogan ve internet sayfası bilgilerinin hareketsiz olarak aktarıldığı görüntüden oluşmaktadır.

Dil katmanı bu televizyon reklamında sözlü ve yazılı olarak bulunmaktadır. Sözlü dildeki iletiler dış seste erkek bir konuşucunun sesi aracılığıyla monolog biçiminde aktarılmaktadır. Bu iletilerin bir kısmı reklamda ayrıca yazılı olarak da yinelenmektedir. Böylelikle izleyiciler reklamdaki ürünlere ilişkin sesli olarak duydukları bazı ürün özellikleri, marka adı ve slogan gibi bilgileri görsel olarak da alımlar ve reklamın hedef kitle üzerindeki etkisi pekiş̧irilmiş olur. Yazılı dil bu reklamda hem hareketsiz hem de hareketli olarak kullanılmıştır. Hareketsiz olarak iletilen bilgiler marka adı, marka sloganı ve internet sayfası adresidir. Bu bilgilerin tamamının son sahnede yer alması, izleyiciler ve Ritter Sport arasında internet ortamında marka bağlılığının oluşturulmasının amaçlandığına işaret etmektedir. Çikolataların gösterildiği bazı sahnelerde Almancada "yeni" anlamına gelen "neu" sıfatı reklamda hareket ettirilerek ürünün yeni olma özelliğine vurgu yapılmaktadır. İncelenen reklamda kullanılan diğer sözcük türleri ad ve eylemdir. Yapılan incelemede yabancı dilde sözcüklere ve neolojizmlere rastlanmamıştır. En sık tekrarlanan sözcüğün marka adı olduğu belirlenmiştir. Reklamdaki çikolata çeşitlerinin türünü ve bazı bileşenlerini öne çıkarmak amacıyla "Winter (kış)", "Orangen-Marzipan (Portakallı badem ezmesi)", "Vanillekipferl (Vanilyalı ay kurabiyesi)", "Nuss (Fındık)" ve "Nugatcreme (Fındık kreması)" gibi çeşitli adlardan, ürünlerin fiziksel özellikleriyle ilgili bilgi vermek için "quadratisch (kare biçiminde)", "praktisch (pratik)" sıfatlarından, tatlarını vurgulamak için ise "schmecken (lezzetli olmak)" eyleminden yararlanıldığı görülmektedir. Tümce yapıları düzleminde yapılan incelemede metinde yalnızca bir bildirme tümcesi ve bir eksiltili tümceye rastlanmıştır. Her iki tümce de kısadır. Bunlarda ilki olan "So schmeckt der Winter" ${ }^{4 \prime \prime}$ bir bildirme tümcesidir ve reklamı izleyenlerin dilsel olarak alımladığı ilk yapıdır. Bu tümce izleyicilerin ilgisini çekerek onları reklamın devamı izlemeye yönlendirmektedir. Reklamın devamında dış sesteki konuşucu üzerinden sesli olarak aktarılan "Schon vor

\footnotetext{
4 Türkçe karşılığı: Kışın tadı böyledir. Çeviri yazar tarafından yapılmıştır.
} 
dem ersten Schnee erhältlich"5 tümcesi eksiltili yapısıyla ürünün bir süre önce satışa çıktığı yönünde izleyicileri bilgilendirmektedir. Wintersorten reklamında hedef kitleye açık bir biçimde belirli bir kişi adılı yerine marka adı olan Ritter Sport üzerinden örtük bir biçimde seslenildiği belirlenmiştir. Marka adı reklamda hem sözlü hem de yazılı olarak yinelenerek hedef kitle arasında herhangi bir ayrım yapmaksızın ilgili markanın çikolatalarını tüketen tüm kullanıcılarına seslenilmektedir.

Görüntü katmanındaki ilk incelemede reklamdaki en baskın renklerin kahverengi ve mavi oldukları bulgulanmıştır. Kahverengi reklamda tanıtılan çikolatalara, mavi ise ürün paketlerinin rengine gönderimde bulunmaktadır. Alt katman olarak bu renklerin neredeyse tüm sahnelerde arka arkaya kullanılması sayesinde görüntüler arasındaki geçişler ve gösterilen nesneler arasında bağlantı kurulması kolaylaştırılmaktadır. Reklamdaki diğer renkler lacivert, sarı, turuncu, yeşil, bej ve beyazdır. Lacivert, reklamı veren çikolata markasının kurum rengidir. Ritter Sport'un kurumsal renk olarak kalite ve resmiyeti temsil eden laciverti tercih etmesi, bireylerin zihninde markaya yönelik güçlü bir imaj oluşturulmasının amaçlandığını göstermektedir. Reklamda karşılaşılan diğer renkler olan turuncu ve sarı ise çikolatalar ile portakal ya da vanilyalı ay kurabiyesi gibi vurgulanmak istenen bazı temel ürün bileşenleri arasında ilişki kurulmasını sağlamaktadır (bkz. çekim planları $\mathrm{N}^{\circ} 4, \mathrm{~N}^{\circ} 5$ ve $\mathrm{N}^{\circ} 7$ ). Yeşil renk içinse farklı bir durum söz konusudur. Bu renk ile ürün içeriği veya ürünün kendisi arasında herhangi bir bağlantı olmadığından izleyicilerin dikkatini ürün paketlerine çekmek için kullanıldığı söylenebilir (bkz. çekim planları $\mathrm{N}^{\circ} 6$ ve $\mathrm{N}^{\circ} 7$ ). Reklamdaki kadın figürün gösterildiği sahnelerde turuncu, bej ve kahverengi gibi sıcak renklerin baskın olduğu saptanmıştır (bkz. çekim planları №2 ve $N^{\circ} 3$ ). Kadının evde olması bu reklamda aktarılmak istenen soğuk kış günlerinin keyfine sıcak bir ev ortamında bir parça çikolata ile varılması anlamın pekiştirilmesine yardımcı olmaktadır. Ürünlerin ön planda olduğu diğer sahnelerde arka planda beyaz renkten yararlanılarak çikolatalarla belli ürün içerikleri vurgulanarak izleyiciler için ilgi çekici hale getirildiği görülmektedir. Yapılan incelemede çikolataların gösterildiği sahnelerde parlak (bkz. çekim planları $\mathrm{N}^{\circ} 4, \mathrm{~N}^{\circ} 5, \mathrm{~N}^{\circ} 6$ ve $\mathrm{N}^{\circ} 7$ ), kadın figürün rol aldığı sahnelerde (bkz. çekim planları $\mathrm{N}^{\circ} 2$ ve $\mathrm{N}^{\circ} 3$ ) ise normal ışıklandırma tekniklerinden yararlanıldığı saptanmıştır. Ürünlerin ve kadının bulunduğu sahnelerde farklı aydınlatma yöntemleri kullanılarak figürün arka plana itilerek reklamı yapılan çikolataların vurgulanması sağlanmıştır.

Wintersorten reklamında yakın çekim, göğüs çekim ve uzak çekim olmak üzere üç farklı çekim ölçeği kullanıldığı belirlenmiştir. Reklamın ilk sahnesinde Ritter Sport

5 Türkçe karşılığı: İlk kardan önce mevcut. Çeviri yazar tarafından yapılmıştır. 
çikolataların tamamını bir arada gösterebilmek için uzak çekim ölçeğinden yararlanılmıştır. Kadın figürün bulunduğu bir sahnelerde göğüs ve yakın çekimden yararlanılmıştır (bkz. çekim planları $\mathrm{N}^{\circ} 2$ ve $\mathrm{N}^{\circ} 3$ ). Böylelikle figürün elleri, kanepedeki oturuşu, mimikleri ve çikolata yerken eriştiği haz görsel olarak vurgulanmıştır. Reklamın devamında yoğun olarak yakın çekim ile görüntüleme yapılarak tanıtılan çikolatalar ile bazı bileşenlerinin fiziksel görüntüleri detaylı olarak yakın planda gösterilmiş ve hedef kitlenin zihninde Ritter Sport çikolatalarının tazeliğine ve lezzetine ilişkin bir anlam üretilmeye çalışılmıştır (bkz. çekim planları $\mathrm{N}^{\circ} 4, \mathrm{~N}^{\circ} 5, \mathrm{~N}^{\circ} 6, \mathrm{~N}^{\circ} 7$ ve $\mathrm{N}^{\circ} 8$ ). Reklamın genelinde normal bakış perspektifi baskındır. Çikolatalar izleyicilere göz hizasında gösterilerek ulaşılabilir oldukları izlenimi yaratılmaktadır. Yalnızca kadın figürün çikolata yediği sahnede tepeden bakış perspektifiyle görüntü alınmıştır (bkz. çekim planı №3). Kameranın yukarıdan çekim yapması sayesinde reklamı izleyenlerin görebilecekleri figürün mimikleri ve çikolata ile kısıtlanarak, hedef kitlenin zihninde çikolata ve kadının duyduğu haz arasında bağlantı kurması sağlanmaktadır.

Reklam süresince arka fonda yavaş bir ritim ve aynı tonda çalan enstrümantal caz müzik kullanılmıştır. Ritim ve tonun reklam içerisinde sabit kalması reklamın sürekliliğine katkı sağlamaktadır. Kullanılan müziğin caz türünde olması izleyiciler üzerinde bu reklamdaki çikolataların elit ve kaliteli olduğuna yönelik bir çağrışım yaratmakta ve potansiyel Ritter Sport tüketicilerinin bazı özelliklerine de gönderimde bulunmaktadır. Bu bağlamda müziğin bu reklamdaki işlevlerinin hedefleme ve çağrışım yaratma olduğu görülmektedir. Ses katmanına yönelik çözümlemede reklam süresince arka planda aynı tonda ve ritimde yapay bir zil sesi kullanıldığı belirlenmiştir. Ses katmanı bu reklamda tek başına belli bir anlam ifade etmiyor gibi görünmekle birlikte aslında yaklaşmakta olan kışa ve noele gönderimde bulunarak reklamı yapılandırmaktadır.

Katmanlararası ilişkiler ölçütüne yönelik çözümlemede dağılım oranı açısından bu reklamdaki en baskın katmanların dil ile görüntü olduğu belirlenmiştir. Reklam süresince arka planda kullanılan müzik ile ses ise dil ve görüntü katmanlarıyla karşılaştırıldıklarında daha düşük bir anlam yaratma potansiyeline sahiptir. Bu bakımdan dağılım oranına göre müzik ikinci, ses ise üçündü sıradadır. Reklamdaki görüntü ve dil katmanlarının birbirlerine sözcük alt katmanı düzleminde, ses ve müzik katmanlarının ise ritim alt katmanı ile bağlandığı belirlenmiştir. Örneğin kadın figürün çikolata yediği sahnede (bkz. çekim planı $N^{\circ}$ 3) dil katmanındaki "So schmeckt der Winter" tümcesi, görüntü katmanında tepeden bakış ve yakın çekim ile öne çıkarılan kadının çikolatayı ısırdıktan sonraki mimikleri ile

6 Türkçe karşılığı için bkz.: 4. dipnot. 
desteklenmektedir. Kadın figürün yaşadığı duygusal haz ayrıca arka fonda çalan caz müzik ve zil sesi üzerinden de pekiştirilmektedir. Benzer biçimde çikolataların ve öne çıkarılmak istenen bazı temel bileşenlerinin bulunduğu sahnelerde (bkz. çekim planları $\mathrm{N}^{\circ} 4, \mathrm{~N}^{\circ} 5$ ve $\left.\mathrm{N}^{\circ} 6\right)$ görüntü katmanında gösterilen portakallı badem ezmesi, vanilyalı ay kurabiyesi ve fındık maddeleri dış sesteki konuşucunun aktardığı "Orangen-Marzipan”, "Vanillekipferl" ve "Nuss" sözcükleri üzerinden dilsel olarak da vurgulanmaktadır. Bu çekim planlarında ayrıca dil katmanında yazılı olarak yinelenen "neu (yeni)" sıfatı ve çikolata paketlerinin renkleri arasında da anlamsal açıdan bir bağlantı olduğu görülmektedir. Paketlerin canlı renkleri tanıtılan çikolata çeşitlerinin yeni olduğuna gönderim yapmaktadır. Bununla birlikte reklamda tanıtılan ürün çeşitlerinin belirleyicisi olarak kullanılan “Winter (kış)" sözcüğü ve kış mevsimini çağrıştıran noel, görüntü katmanındaki soğuk hava atmosferi atmosferi ve arka fondaki zil sesi ile desteklenmektedir. Caz türünde bir müziğin tercih edilmesi ise hem potansiyel ürün tüketicilerine işitsel olarak işaret etmekte hem de tanıtılan çikolata çeşitlerinin görüntü katmanında gösterilen ev ve benzeri kapalı mekanlarda tüketilebilen bir ürün olduğuyla ilgili çağrışımlar yapmaktadır (bkz. çekim planları $\mathrm{N}^{\circ} 2$ ve $\mathrm{N}^{\circ} 3$ ). Sonuç olarak bu reklamdaki her bir katmanın birbiriyle bağlantılı, anlamsal, işlevsel ve biçimsel açıdan tutarlı bir bütünlük oluşturdukları belirlenmiştir.

\section{2. Örnek Çözümleme: Eti Karam Bitter Reklamı}

\begin{tabular}{|c|c|c|c|c|}
\hline Çekim Plani & $N^{\circ} 1(00: 01)$ & $N^{\circ} 2(00: 04)$ & $N^{\circ} 3(00: 05)$ & $N^{\circ} 4(00: 10)$ \\
\hline GÖRÜNTÜ IÇERIǴi & $\begin{array}{l}\text { Selçuk Yöntem bir kafede } \\
\text { kendisine kahve servis } \\
\text { edilirken görüntüleniyor. } \\
\text { Takım elbise giymiş. } \\
\text { Eliyle cebinden birşey } \\
\text { çıkartıyor. }\end{array}$ & $\begin{array}{l}\text { Selçuk Yöntem cebinden } \\
\text { çıkardığı çikolatayı } \\
\text { kırıyor. }\end{array}$ & $\begin{array}{l}\text { Krem rengi bir elbise } \\
\text { giyen genç bir kadın } \\
\text { ve Selçuk Yöntem } \\
\text { konuşuyorlar. }\end{array}$ & $\begin{array}{l}\text { Selçuk Yöntem kadına bir } \\
\text { parça çikolata uzatıyor. } \\
\text { Arka planda cafenin bir } \\
\text { bölümü görünüyor. }\end{array}$ \\
\hline ÇEKiM ÖLÇEĞi & Göğüs çekim & Ayrıntı çekim & Yakın çekim & Diz çekim \\
\hline $\begin{array}{l}\text { Kamera } \\
\text { Perspektifi }\end{array}$ & Normal bakış & Tepeden bakış & $\begin{array}{l}\text { Alttan bakış (Omuz } \\
\text { çekim) }\end{array}$ & Normal bakış \\
\hline DiL (sözlü) & $\begin{array}{l}\text { İç ses } \\
\text { Selçuk Yöntem: } \\
\text { "Teşekkürler" }\end{array}$ & 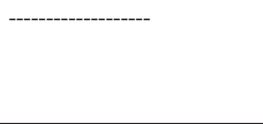 & $\begin{array}{l}\text { İç ses } \\
\text { 1. Kadın: "Ya önce acaba } \\
\text { o mu? dedim, ama } \\
\text { Karam'ı kırdığınız anda..." }\end{array}$ & $\begin{array}{l}\text { İç ses } \\
\text { Selçuk Yöntem: } \\
\text { "Buyurun!" }\end{array}$ \\
\hline DiL (yazılı) & 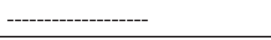 & --- & 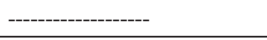 & -- \\
\hline Muzik & Enstrümental Caz & Enstrümental Caz & Enstrümental Caz & Enstrümental Caz \\
\hline SES & - & Çikolata kırılma sesi & - & --- \\
\hline
\end{tabular}




\begin{tabular}{|c|c|c|c|c|}
\hline ÇeKim Plani & $N^{\circ} 5(00: 11)$ & $N^{\circ} 6(00: 12)$ & $N^{\circ} 7(00: 14)$ & $8(00: 21)$ \\
\hline GöRÜNTÜ IÇCERIĞi & $\begin{array}{l}\text { Selçuk Yöntem bir parça } \\
\text { daha çikolata kırıyor. }\end{array}$ & $\begin{array}{l}\text { Başka bir genç kadın } \\
\text { Selçuk Yöntem'in } \\
\text { yanına geliyor. Kadının } \\
\text { üzerinde açık mavi bir } \\
\text { gömlek var. }\end{array}$ & $\begin{array}{l}\text { Selçuk Yöntem bu kadına } \\
\text { da bir parça çikolata } \\
\text { uzatıyor. Arka planda } \\
\text { cafede oturan diğer } \\
\text { insanlar görünüyor. }\end{array}$ & $\begin{array}{l}\text { Üçüncü bir genç kadın } \\
\text { Selçuk Yöntem'in } \\
\text { yanına geliyor. Kadının } \\
\text { üzerinde siyah deri } \\
\text { bir ceket ve beyaz bir } \\
\text { bluz var. }\end{array}$ \\
\hline ÇEKiM ÖıçEĞi & Ayrıntı çekim & Yakın çekim & Göğüs çekim & Göğüs çekim \\
\hline $\begin{array}{l}\text { Kamera } \\
\text { Perspektifi }\end{array}$ & Tepeden bakış & $\begin{array}{l}\text { Alttan bakış (Omuz } \\
\text { çekim) }\end{array}$ & Normal bakış & $\begin{array}{l}\text { Alttan bakış (Omuz } \\
\text { çekim) }\end{array}$ \\
\hline DiL (sözlü) & ------------------ & $\begin{array}{l}\text { İç ses } \\
\text { 2. Kadın: "Merhabalar! } \\
\text { Yine Karam yiyorsunuz" }\end{array}$ & $\begin{array}{l}\text { İç ses } \\
\text { Selçuk Yöntem: "Buyurun!" }\end{array}$ & $\begin{array}{l}\text { İç ses } \\
\text { 3. Kadın: “Siz? Karam } \\
\text { reklamındaki beyefendi } \\
\text { di mi?"'”' }\end{array}$ \\
\hline DiL (yazılı) & 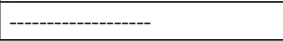 & ---------------- & 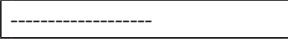 & -------------- \\
\hline Muzik & Enstrümental Caz & Enstrümental Caz & Enstrümental Caz & Enstrümental Caz \\
\hline Ses & Çikolata kırılma sesi & - & 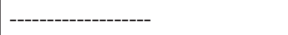 & - \\
\hline Çekim Planı & $N^{\circ} \mathbf{9}(00: 23)$ & $N^{\circ} 10(00: 27)$ & $\mathrm{N}^{\circ} 11(00: 30)$ & $\begin{array}{l}\mathbf{N}^{\circ} 12 \text { (00:32) } \\
\text { Mostur Bitter } \\
\text { Cof }\end{array}$ \\
\hline GöRÜNTÜ IÇCERIĞi & $\begin{array}{l}\text { Selçuk Yöntem bu kadına } \\
\text { da bir parça çikolata ikram } \\
\text { ediyor. }\end{array}$ & Kadın çikolatayı alıyor. & $\begin{array}{l}\text { Selçuk Yötem kadına } \\
\text { bakıyor. }\end{array}$ & $\begin{array}{l}\text { Reklamı yapılan } \\
\text { çikolatanın tüm çeşitleri } \\
\text { marka adı ve ürün } \\
\text { sloganı ile birlikte } \\
\text { gösteriliyor. }\end{array}$ \\
\hline ÇеKiM ÖıÇEĞi & Göğüs çekim & Göğüs çekim & Yakın çekim & Yakın çekim \\
\hline $\begin{array}{l}\text { Kamera } \\
\text { Perspektifi }\end{array}$ & $\begin{array}{l}\text { Tepeden bakış (Omuz } \\
\text { çekim) }\end{array}$ & $\begin{array}{l}\text { Alttan bakış (Omuz } \\
\text { çekim) }\end{array}$ & Tepeden bakış & Normal bakış \\
\hline DiL (sözlü) & $\begin{array}{l}\text { İç ses } \\
\text { Selçuk Yöntem: "Evet } \\
\text { benim, lütfen siz de alın." }\end{array}$ & $\begin{array}{l}\text { İç ses } \\
\text { 3. Kadın: "İnsan } \\
\text { bitterden vazgeçemiyor } \\
\text { tabi di mi?" }\end{array}$ & $\begin{array}{l}\text { İç ses } \\
\text { Selçuk Yöntem: } \\
\text { "Vazgeçemiyor" }\end{array}$ & $\begin{array}{l}\text { İç ses } \\
\text { Selçuk Yöntem: "Eti } \\
\text { Karam Bitter, Meşhur } \\
\text { Bitter" }\end{array}$ \\
\hline DiL (yazılı) & ---------------- & 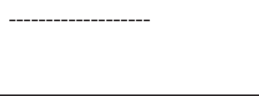 & ------------------- & $\begin{array}{l}\text { Et, Karam Bitter } \\
\text { Meşhur Bitter } \\
\text { Eti }\end{array}$ \\
\hline Muzik & Enstrümental Caz & Enstrümental Caz & Enstrümental Caz & Enstrümental Caz \\
\hline SES & ------------------- & 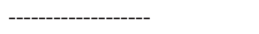 & 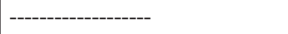 & 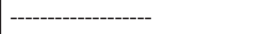 \\
\hline
\end{tabular}

Örnek analizde yararlanılan Türkçe televizyon reklamında Eti Karam Bitter adlı çikolata tanıtılmaktadır. Reklamın toplam süresi 32 saniyedir. Markanın tanıtım yüzü Türk tiyatro, sinema ve dizi oyuncusu Selçuk Yöntem'in kendisi olarak rol aldığı bu reklamın ilk sahnesinde bir kafede tek başına oturan ünlü oyuncu, sipariş ettiği kahveyle birlikte yemek için cebinden bir çikolata çıkarır. Çikolatadan bir parça kopardığı anda yanına sırayla üç farklı genç kadın gelir ve Selçuk Yöntem her birine birer parça çikolata ikram 
ederek kendisi için yeni bir parça daha kırar. Reklam, tanıtılan bitter çikolatanın beş değişik çeşidinin marka adı ve ürün sloganı ile bir arada gösterildiği sahne ile sona erer.

Dil katmanı örnek çözümleme için seçilen Türkçe reklamda sözlü ve yazılı olarak kullanılmıştır. Sözlü dildeki iletiler, reklamda rol alan figürlerin kendi aralarındaki konuşmaları üzerinden iç seste diyalog biçiminde aktarılmaktadır. Yazılı dildeki bilgiler ise yalnızca son sahnede marka adı, ürün sloganı ve ürün adı olarak karşımıza çıkmaktadır. Bu bilgilerin eş zamanlı olarak iç sesteki konuşuculardan biri olan Selçuk Yöntem tarafından da sözlü biçimde yinelendiği belirlenmiştir. Böylelikle reklamı izleyenler tanıtılan ürünün adını, markasını ve sloganını hem görsel hem de dilsel olarak algılayabilmekte ve reklamın hedef kitle üzerindeki etkisi de artırılmaktadır. Sözcük düzleminde yapılan analizde Eti Karam Bitter reklamında kullanılan sözcük türlerinin ad, eylem ve sıfat olduğu bulgulanmıştır. Marka adında geçen "karam" sözcüğü ile çikolatanın türünü bildiren "bitter" sıfatının reklamda en sık tekrarlanan sözcükler oldukları saptanmıştır. Reklam boyunca yazılı ve sözlü biçimde yinelenen bu iki sözcük üzerinden hedef kitlenin zihninde "bitter = Karam" şeklinde bir eşitlik kurulması sağlanmaktadır. Reklamdaki diğer sözcük türlerine bakıldığında "vazgeçmek" eyleminin öne çıktığı görülmektedir. İki kez sözlü olarak figürler arasındaki diyalogda tekrarlanan bu eylem, Türkçede olumsuzluk bildiren "-mi" eki ile birlikte kullanılarak reklamda gösterilen bitter çikolatanın lezzeti ve kalitesi bakımından vazgeçilemeyen bir ürün olduğuna ilişkin bir anlam yaratılmaya çalışılmaktadır. Bir diğer dikkat çeken sözcük ise "meşhur" sıfatıdır. Ürün türüyle birlikte "Meşhur bitter" olarak tamlama biçiminde kullanılan bu sıfat ile ürünün uzun süredir piyasada bulunan ve herkes tarafından tanınan bir çikolata olduğuna gönderim yapılmaktadır. Bu reklamda dördü soru, üçü bildirme, ikisi ise emir tümcesi olmak üzere kısa ve orta uzunlukta tümcelerin bulunduğu belirlenmiştir. Markanın bu tercihi diyalog biçimindeki sözlü dil kullanımına uygundur. Soru tümceleri arasında çekim planı № 8 'deki "Siz? Karam reklamındaki beyefendi di mi?" sorusu Selçuk Yöntem'in Eti Karam çikolatalarının tanıtıldığı başka reklamlarda da rol aldığına işaret etmektedir. Benzer şekilde çekim planı Nº'daki "Yine Karam yiyorsunuz" tümcesi de Selçuk Yöntem'in bu markanın tanıtım yüzü olduğunu ve Karam çikolatalarını tercih ettiğini izleyicilere hatırlatmaktadır. Çekim planı N¹0'daki “İnsan bitterden vazgeçemiyor tabi di mi?" sorusu ise, izleyicileri düşünsel bir sürece sokan retorik bir soru olması bakımından özellikle dikkat çekicidir. Selçuk Yöntem'in soruya cevabı olan "Vazgeçemiyor” tümcesi doğrudan reklamdaki çikolata ile bağlantılı olmakla birlikte aynı zamanda bir dönem rol aldığı Aşk-ı

7 Bu sözcük Türkçeye İngilizceden geçmiştir, ancak zaman içinde Türkçeye yerleşmiş olması ve Türkçede başka bir karşılığı olmaması bakımından, bu çalışmada yabancı dildeki sözcük kategorisine alınmamıştır. 
Memnu adlı dizide ${ }^{8}$ canlandırdığı karaktere ${ }^{9}$ ve bu karakterin eşi olan Bihter adlı kadından vazgeçememesine de gönderim yapmaktadır. Bu anlamda "bitter" ve "Bihter" sözcükleri arasındaki sesletim benzerliği üzerinden metinlerarası bir geçiş yapılarak reklamı izleyenlerin ilgisinin canlı tutulmasının sağlanmaya çalışıldığı düşünülebilir. Reklamdaki emir tümcelerinin tamamının Selçuk Yöntem tarafından kadın figürlere çikolata ikram ederken (bkz. çekim planları $\mathrm{N}^{\circ} 4, \mathrm{~N}^{\circ} 7$ ve $\mathrm{N}^{\circ}$ 9) kullanıldıkları belirlenmiştir. Bu tümceler aracılığıyla aynı zamanda reklamın hedef kitlesine de hitap edilmekte ve tanıtılan çikolatayı satın almaları için harekete geçmeleri beklenmektedir. Eti Karam Bitter reklamında izleyicilere seslenilirken hem benöyküsel hem de senöyküsel biçimlerin tercih edildiği görülmektedir. Benöyküsel seslenme, reklamda çekim planı №9'da Selçuk Yöntem'in “Evet benim” tümcesinde karşımıza çıkmaktadır. Tümcedeki "ben” kullanımıyla olay örgüsünün Selçuk Yöntem tarafından bizzat deneyimlendiği vurgulanmakta ve reklamın inandırıcılığı artırılmaktadır. Senöyküsel seslenme ise çekim planları $N^{\circ} 4, N^{\circ} 7$ ve Nº'daki emir tümcelerinde (Ör: Lütfen siz de alın) bulunmaktadır. Bu seslenme biçimiyle Eti Karam Bitter çikolatalarının potansiyel tüketicilerine doğrudan reklamdaki ürünü satın almaları için çağrıda bulunulmaktadır.

Görüntü katmanında yapılan ilk çözümlemede reklamın tüm sahnelerinde siyah ve kahverenginin baskın oldukları belirlenmiştir. Her iki renk de reklamı izleyenlerin zihninde bitter çikolatayı da çağrıştırmaktadır. Bu renkler aynı zamanda ortamda bulunan eşyaların ve figürlerin bazılarının giysilerinin rengi olarak karşımıza çıkmaktadır (Ör: Selçuk Yöntem'in üzerindeki ceket siyahtır). Bir alt katman olarak siyah ve kahverenginin rengin reklamın tamamında kullanılması izleyicilerin sahneler arasında geçiş yapabilmelerini ve gördükleri arasında bağlantı kurabilmelerini kolaylaştırmaktadır. Ayrıca resmiyet ve prestiji temsil etmesi bakımından siyah rengin Eti Karam Bitter çikolatalarının kalitesine, kahverenginin ise doğayı çağrıştırması açısından da ürünün lezzetine gönderimde bulundukları söylenebilir. Reklamda karşılaşılan diğer renkler, krem rengi, beyaz, açık mavi, sarı, mor, turuncu, kırmızı ve yeşildir. Bu renkler arasında krem rengi, beyaz, ile açık mavi yalnızca reklamdaki figürlerin kıyafetlerinin rengidir. Turuncu, yeşil, kırmızı ve mor ise çikolata paketlerinin üzerinde tamamlayıcı renk olarak kullanılmıştır. Sarı yalnızca reklamın sonunda siyah fon üzerinde arka plan rengi olarak bulunmaktadır. Bu renklerin birlikteliği reklamın son sahnesine gece karanlığında yansıyan ışıklar gibi bir görünüm kazandırarak görüntüye derinlik katmakta ve ön planda gösterilen çikolata çeşitlerini

\footnotetext{
8 Adı geçen dizi Halid Ziya Uşaklıgil'in aynı adı taşıyan romanından uyarlamadır ve 2008-2011 yılları arasında Kanal D tarafından yayınlanmıştır.

9 Selçuk Yöntem ilgili dizide Adnan Ziyagil adlı varlıklı, saygın, orta yaşlı bir iş adamını canlandırmaktadır.
} 
izleyiciler için çekici kılmaktadır. Reklamda rol alan figürleri, mimiklerini, vücut hareketlerini, ortamı ve tanıtılan çikolatayı ayrıntılı biçimde gösterebilmek için normal ışıklandırmadan, son sahnedeki çikolataları, markayı, ürün adını ve sloganı öne çıkarmak için ise sönük ışıklandırmadan yararlanıldığı bulgulanmıştır. Eti Karam Bitter reklamında ayrıntı, yakın, göğüs ve diz olmak üzere dört farklı ölçekten çekim yapıldığı belirlenmiştir. Reklamın genelinde göğüs ve yakın çekimden görüntü alınmıştır. Selçuk Yöntem gösterildiği bazı sahnelerde (bkz. çekim planları $N^{\circ} 1, N^{\circ} 7, N^{\circ} 9$ ve $^{\circ} 11$ ) göğüs çekimden yararlanıldığı görülmektedir. Bu sayede izleyiciler oyuncunun mimiklerini, vücut hareketlerini, çikolata ile olan ilişkisini, üzerindeki kıyafeti, oturduğu yeri ve bulunduğu mekanının kısıtlı bir bölümünü görebilmektedir. Çikolatanın kırılma sesine gelen ilk iki kadının bulunduğu sahnelerde (bkz. çekim planları $\mathrm{N}^{\circ} 6$ ve $\mathrm{N}^{\circ} 12$ ) ise yakın çekim ile görüntü alınmıştır. Böylece kadınların çikolataya olan arzusunu yansıtan mimikleri (Ör: gülümsemeleri) vurgulanmıştır. Selçuk Yöntem'in cebinden çıkardığı çikolatayı kırdığı sahnelerde (bkz. çekim planları $\mathrm{N}^{\circ} 2$ ve $\mathrm{N}^{\circ} 5$ ) reklamı yapılan çikolatayı paketiyle birlikte yakın planda detaylı olarak gösterebilmek için ayrıntı çekim ölçeğine başvurulmuştur. Reklamda yalnızca bir sahnede diz çekim ölçeği ile görüntü alınmıştır. Selçuk Yöntem'in masasına ilk gelen kadına çikolata uzatırken görüntülendiği bu sahnede (bkz. çekim planı $N^{\circ} 4$ ) kamera kadının dizlerinden yukarısına odaklanarak üzerindeki elbiseyi ve figürlerin bulunduğu ortamın kısıtlı bir bölümünü ayrıntılı olarak göstermektedir. Yapılan incelemede Eti Karam Bitter reklamında normal bakış, alttan bakış ve tepeden bakış olmak üzere üç farklı perspektiften belirli bir sıralamayla10 eşit oranda çekim yapıldığı belirlenmiştir. Reklam boyunca kadın figürler ayakta durmakta, Selçuk Yöntem ise oturmaktadır. Dolayısıyla her iki taraf da birbirinin göz hizasında değildir. Bu açıyı izleyicilere gösterebilmek için kameranın kadınların gösterildiği sahnelerde ağırlıklı olarak alttan bakış ile Selçuk Yöntem'in bulunduğu sahnelerde ise tepeden bakış ile figürlerin omuzları üzerinden çekim yaptığı görülmektedir. Böylelikle reklamı izleyenlerin ekranda gördükleri figürlerin yanındaymış gibi hissetmeleri sağlanmaktadır. Bu kamera açıları izleyicilere Selçuk Yöntem ile kadınlar arasında çikolata aracılığıyla kurulan ilişki hakkında da bilgi vermektedir. Söz konusu ilişkide alttan bakış ile kadrajlanan kadın figürler istedikleri an Selçuk Yöntem'in elindeki çikolatayı elde edebilecek kadar baskın bir konumdayken, tepeden bakış ile görüntülenen Selçuk Yöntem ve elinde tuttuğu çikolata ise hem reklamdaki kadınlar hem de izleyiciler için erişilebilir bir durumda gösterilmektedir.

10 Çekim planları $\mathrm{N}^{\circ} 1$ ve $\mathrm{N}^{\circ} 6$ arasında kullanılan kamera perspektiflerinin sıralaması: normal bakış, tepeden bakış, alttan bakış, normal bakış, tepeden bakış ve alttan bakıştır. Çekim planları $N^{\circ} 7$ ve $N^{\circ} 12$ arasında ise sırasıyla normal bakış, alttan bakış, tepeden bakış, alttan bakış, tepeden bakış ve yeniden normal bakış perspektiflerinden görüntü alınmıştır. 
Müzik katmanı incelemesinde reklam boyunca arka fonda farklı ritimde ve farklı tonda ilerleyen enstrümantal caz müzik çaldığı belirlenmiştir. Caz müzik reklamdaki olay örgüsünün geçtiği kafe ortamı ile uyumlu olmakla birlikte reklamı izleyenlerin zihninde Eti Karam Bitter çikolatalarının elit ve kaliteli olduğuna yönelik bir çağrışım da yaratmaktadır. Ritim ve tonun zaman zaman değişmesi bazı sahnelerde hareketin hızını artırmakta veya yavaşlatmaktadır. Bu anlamda müzik katmanının reklamın bütünlüklü kalmasına ve devamlıı̆̆ına katkı sağladığı görülmektedir. Reklamda tercih edilen müziğin caz türünde olması Eti Karam Bitter çikolatalarını tüketen kişilerin bazı özelliklerine de gönderimde bulunulmaktadır. Dolayısıyla müzik katmanının bu reklamda çağrışım yapma işlevi dışında hedefleme işlevi de taşıdığı söylenebilir. Bu reklamda çekim planları $\mathrm{N}^{\circ} 2$ ve $N^{\circ} 5^{\prime}$ te tanıtılan ürün ile doğrudan bağlantılıçikolata kırılma/çatırdama sesinin kullanıldığı saptanmıştır. Bu ses, reklamı izleyenlerin zihninde doğrudan Eti markasına ilişkin somut bir algı oluşturmamaktadır, ancak çikolatanın tazeliği konusunda olumlu bir çağrışım yaratılmasına katkı sağlayarak izleyicileri bu çikolatayı satın almaları için örtük biçimde yönlendirmektedir. Bu anlamda ses katmanının çözümlenen örnek Türkçe reklamda metni yapılandırma işlevi taşıdığı söylenebilir.

Katmanlararası ilişkiler üzerine yapılan incelemede Türkçe reklamdaki dil ve görüntü katmanlarının kullanım oranlarının eşit olduğu saptanmıştır. Bu iki katmanın reklamdaki eşit dağılımının temel nedeni, sözlü iletilerin figürlerin diyalog biçimindeki konuşmaları üzerinden iç seste aktarılmasıdır. Konuşan kişilerin ekranda görünmeleri, iki katmanın dağılım oranlarının aynı olmasına yol açmaktadır. Reklamın tamamında arka fonda duyulan müzik anlam yaratma potansiyelinin dil ve görüntüye göre daha düşük olması bakımından ikinci derecede baskın bir katmandır. Yalnızca iki sahnede kullanılan ses katmanı ise üçüncü sırada bulunmaktadır.

Dil ve görüntü katmanları arasındaki bağlantılar kapsamında, bu iki katmanın birbirlerine sözcük alt katmanı düzleminde bağlandıkları belirlenmiştir. Figürlerin birbirleriyle konuşurken gösterildikleri sahnelerde (bkz. çekim planları $N^{\circ} 1, N^{\circ} 3, N^{\circ} 6, N^{\circ} 7$, $\mathrm{N}^{\circ} 8, \mathrm{~N}^{\circ} 9, \mathrm{~N}^{\circ} 10$ ve $\mathrm{N}^{\circ} 11$ ) kameranın konuşan kişiyi göstermektedir. Örneğin Selçuk Yöntem'in kendisine sorulan "Siz? Karam reklamındaki beyefendi di mi?" sorusuna (bkz. çekim planı $N^{\circ} 9$ ) verdiği “Evet benim” cevabı ile bu kişinin reklamdaki varlığı dilsel olarak, kameranın tepeden bakış ve göğüs çekim ile kadrajlama sayesinde de görsel olarak vurgulanmıştır. Benzer biçimde Selçuk Yöntem'in kadınlara çikolata uzatırken gösterildiği sahnelerdeki (bkz. çekim planları $\mathrm{N}^{\circ} 4, \mathrm{~N}^{\circ} 7$ ve $\mathrm{N}^{\circ}$ 9) vücut hareketleri, dil katmanındaki "Buyurun" ve "Lütfen siz de alın" tümceleriyle pekiştirilmektedir. Reklamın arka planda 
çalan enstrümantal caz müzik, reklamın erişmek istediği potansiyel hedef kitleyi işitsel olarak temsil etmektedir. Müziğin ritminin reklam süresince zaman zaman değişmesi görüntü katmanında verilen reklam iletisini yavaşlatmakta veya hızlandırmaktadır. Örneğin Selçuk Yöntem'in yanına ilk gelen kadına çikolata ikram ederken gösterildiği sahnede (bkz. çekim planı N4) çalan müziğin ritmi oldukça hızlıdır. Bu ritim, çikolataya uzanan kadının heyecanlı görüntüsünü desteklemektedir. Selçuk Yöntem’in masasına gelen ikinci kadının çikolatayı yerken gösterildiği sahnede (bkz. çekim planı $\mathrm{N}^{\circ} 6$ ) ise ritim çok daha yavaştır, böylece kadının çikolata ile eriştiği haz duygusu vurgulanmaktadır. Selçuk Yöntem'in çikolatadan birer parça kopardığı sahnelerde (bkz. çekim planları N² ve №5) çikolatanın kırılırken ki görüntüsü, çikolatanın tazeliğini çağrıştıran kırılma/çatırdama sesi ile tamamlanmaktadır. Çözümleme sonucunda dağılım oranları farklı olmasına rağmen dil, görüntü, müzik ve ses katmanlarının uyum içerisinde kullanıldığı ve birbirleriyle bağlantılı bir bütünlük oluşturdukları bulgulanmıştır.

\subsection{Karşılaştırma ve Değerlendirme}

Çalışmada çok katmanlı metin yaklaşımıyla incelenen 10 Almanca ve 10 Türkçe televizyon reklamının ayrıntılı analizi sonucunda bu iki dildeki reklamlarda katmanlar ile katmanlararasılık düzleminde benzerlikler ve farklılıklar bulunduğu belirlenmiştir. İlgili benzerlikler ve farklılıklar şöyle sıralanabilir:

Dil katmanı çözümlenen Almanca ve Türkçe televizyon reklamlarının tamamında sözlü ve yazılı biçimde yer almaktadır. Almanca reklamların çoğunda sözlü ve yazılı dilin eşit oranda, Türkçe reklamlarının ise tümünde sözlü dilin yazılı dile oranla daha fazla kullanıldığı belirlenmiştir. Sözlü ve yazılı dilin Almanca ve Türkçedeki dağılımları arasındaki farklıı̆ın nedeni reklamı veren marka ya da tanıtılan ürünle ilişkili olabilir (Karş. Janich, 2010, s. 114; Stöckl, 2012, s. 245). Sözlü dildeki iletiler Almanca reklamların tamamında dış sesteki bir konuşucu tarafından, Türkçe reklamların büyük bir kısmında ise reklamda rol alan figürlerin kendi sesleri üzerinden aktarılmaktadır. Almancada dış sesin, Türkçede ise iç sesin tercih edilmesi, Türkçe reklamlarda ünlü kişilerin rol almasından kaynaklanmaktadır. Konuşan kişilerin aynı zamanda ekranda görünmesi ve çikolatayla olan ilişkilerini kendi deneyimleri üzerinden anlatmaları, izleyicilerin zihninde çikolatanın lezzeti ve kalitesi konusunda olumlu bir etki bırakmaktadır. Yazılı dilin incelenen Almanca ve Türkçe reklamların tamamında son sahnelerde kullanıldığı görülmektedir. Yazılı olarak iletilen bilgiler her iki dildeki reklamlarda da marka adı, ürün adı, marka sloganı, web sayfası adresi, sosyal medya linkleri ve çeşitli hashtaglerdir (Karş. 
Wyss, 2011, s. 287). Bu benzerlik reklamların üretildikleri dilden bağımsız olarak küresel reklamcılık anlayışının zorunlu kıldığı bazı ortak özelliklere sahip olmaları ve belli bir formatta hazırlanmaları gerektiğiyle ilişkilendirilebilir (Karş. Buggisch, 2008, s. 113-116; Opiłowski, 2015, s. 96).

Çözümlenen reklamların tamamında en sık kullanılan sözcüklerin marka adları ve "Schokolade/çikolata" sözcüğü olduğu belirlenmiştir (Karş. Sowinski, 1998, s. 69-70; Mahovský, 2007, s. 36; Atasoy, 2019a, s. 276; 2019b, s. 323). Marka adlarının reklamlar süresince devamlı olarak belli aralıklarla yinelenmesi, hedef kitlenin zihnine yerleşmesini sağlanmaktadır. Reklamı yapılan ürünü işaret eden "Schokolade/çikolata" sözcüğünün tekrarlanması ise reklamı yapılan ürünün ne olduğunu dilsel olarak vurgulamaktadır. Her iki dildeki reklamlarda da "neu/yeni" sıfatına rastlanmıştır (Karş. Mahovský, 2007, s. 37; Atasoy, 2019a, s. 277; 2019b, s. 323-324). Bu sıfat Almanca reklamlarda en sık yinelenen sıfat olmasına rağmen, Türkçe reklamlarda ikinci sırada tekrarlanan bir sıfattır. Söz konusu farklılığın nedeni Almaca reklamlarda yeni ürünlerin, Türkçe reklamlarda ise uzun süredir piyasada satışta olan ürünlerin tanıtılmasından kaynaklanmaktadır. Íki dil arasındaki bir başka farklılık da "werden/olmak" eyleminin kullanımında görülmektedir (Karş. Romanenko, 2004, s. 12; Kunt, 2007, s. 237-244; Atasoy, 2019a, s. 277). Bu eylem Almanca reklamlarda "Jetzt Fan werden"11 örneğindeki gibi hedef kitleyi Ritter Sport markasının sosyal medya hesaplarına yönlendirmek için, Türkçede ise "Bitter Karam gibi olur" tümcesindeki gibi bitter çikolata dendiğinde izleyicilerin aklına yalnızca Eti markasının ürettiği bitter çikolataların gelmesi gerektiğini vurgulamak için kullanılmaktadır. Sözcük türlerine yönelik yapılan ayrıntılı çözümlemede bazı Türkçe televizyon reklamlarında tanıtılan ürün adlarında İngilizcede yoğun anlamına gelen "intense" sözcüğüne rastlanmıştır (Karş. Şenöz-Ayata \& Atasoy, 2018, s. 14; Atasoy, 2017, s. 327; 2019a, s. 278). Sadece ürün adında yabancı dilde bir sözcükten yararlanılması aracılığıyla, Eti ürünleri piyasadaki benzerlerinden daha fazla ve daha yoğun çikolata içerme özelliği üzerinden ayrıştırılmakta ve bu markanın ürettiği çikolataların izleyicilerin zihnindeki çağrışım değerinin güçlenmesine katkı sağlanmaktadır. Bu anlamda reklamı veren Türk çikolata üreticisi Eti'nin piyasada seçkinlik kazanma eğilimi olduğu düşünülebilir (Karş. Mahovský, 2007, s. 45). Ürün adında yabancı dilde sözcük kullanılması Eti'nin 2009'da başladığı uluslararasılaşma ${ }^{12}$ hedefini devam ettirdiğini de göstermektedir. Bütüncedeki Almanca reklamlarda yabancı dilde sözcüklere rastlanmamıştır. Bunun

11 Türkçe karşılığı: Şimdi fan olun. Çeviri yazar tarafından yapılmıştır.

12 Eti markası 2009 yılında ürünleri için en fazla uluslararası marka başvurusu yapan şirket seçilmiştir. Ayrıntılı bilgi için bkz.: https://www.etietieti.com/eti-tarihce. Son erişim tarihi 07.01.2018. 
nedeni tanıtılan ürünlerin türüne ya da Ritter Sport markasının değerlerine dayandırılabilir (Karş. Buggisch, 2008, s. 106; Elsen, 2008, s. 102; Atasoy, 2016, s. 95; 2017, s. 322; ŞenözAyata \& Atasoy, 2018, s. 16).

Tümce türü düzleminde yapılan ayrıntılı çözümlemede bütüncede yararlanılan Almanca ve Türkçe reklamlarda ürünleri tanıtmak için ağırlıklı olarak kısa tümcelerden yararlanıldığı görülmektedir. Ritter Sport ve Eti markalarının bu tercihi izleyicilere tanıtılan çikolatalar hakkındaki temel bilgileri en kısa yoldan paylaşarak onları sıkmadan ve ürüne olan ilgilerini kaybetmeden bu ürünleri satın almaları konusunda harekete geçirmeyi amaçladıklarına işaret etmektedir (Karş. Stöckl, 2004, s. 239; Mahovský, 2007, s. 43; Janich, 2010, s. 181). İncelenen Almanca reklamlarda eksiltili tümceler, ünlem tümceleri, bildirme tümceleri ve soru tümcelerinin, Türkçe reklamlarda ise bildirme tümceleri, eksiltili tümceler, soru tümceleri, emir tümceleri ve ünlem tümceleri kullanıldığı belirlenmiştir (Karş. Sowinski, 1998, s. 63; Kunt, 2007, s. 233; Romanenko, 2014: 23; Atasoy, 2017, s. 322326; 2019a, s. 279). Almanca reklamlarda eksiltili tümceler, Türkçede ise bildirme tümceleri öne çıkmaktadır. Bu farklılığın nedenlerinden biri, Almanca reklamların yayın sürelerinin Türkçeden daha kısa olmasıdır. Reklama ayrılan sürenin uzunluğu kullanılacak tümce türlerinin seçimine etki eden en temel unsurlardan biridir. Bir başka neden de eksiltili tümcelerin Almancanın dil yapısına Türkçe ile karşılaştırıldığında çok daha uygun olmasıdır (Karş. Atasoy, 2019b, s. 314). Çözümlenen Almanca reklamlarda izleyicilere açık biçimde belirli kişi adılları (Sie, du, unser) belgisiz adıllar (alle) aracılığıyla benöyküsel ve/ veya senöyküsel biçimde ya da marka adı olan Ritter Sport üzerinden örtük biçimde seslenildiği belirlenmiş̧tir (Karş. Polajnar, 2005, s. 59; Kunt, 2007, s. 237-249; Buggisch, 2008, s. 104-105; Atasoy, 2016, s. 95; 2017, s. 322; Şenöz-Ayata \& Atasoy, 2018, s. 15-17; Atasoy, 2019b, s. 314). Türkçe reklamlarda ise benöyküsel ve/veya senöyküsel seslenme biçimlerinde birinci ve ikinci tekil kişi adıllarının öne çıktığı saptanmıştır (Karş. Kunt, 2007, s. 237-249; Atasoy, 2016, s. 97; 2017, s. 326; Şenöz-Ayata \& Atasoy, 2018, s. 14). Seslenme biçimleri arasındaki farklılığın nedeni Türkçe reklamlarda rol alan figürlerin ürünler hakkındaki fikirlerini kendi kişisel deneyimlerinden yola çıkarak aktarıyor olmasıyla ilişkilidir.

Dil katmanındaki ayrıntılı çözümlemede Türkçe reklamlardaki kadın ve erkek figürlerin dil kullanımları arasında belirgin bir farklılık olduğu gözlemlenmiştir ${ }^{13}$. İlgili reklamlarda

13 Almanca reklamlarda erkek figürler bulunmamakta, rol alan kadın figürler ise konuşmamaktadır. Bu bakımdan Almanca reklamlarda kadın ve erkek figürlerin dil kullanımlarına ilişkin bir belirleme yapılamamıştır. 
rol alan kadınlar gündelik dilde oldukça basit ifadeler içeren tümcelerle çocuksu olarak nitelendirilebilecek bir üslupla konuşurken, erkekler çok daha yüksek ve standart sayılabilecek bir dil ile konuşmaktadır. Konuşma biçimleriyle bağlantılı olarak kadın figürlerin çikolatayla olan ilişkisi tutkulu ve çocuksu, erkeklerin çikolataya olan yaklaşımının ise oldukça ciddi ve elit göründüğü söylenebilir.

Görüntü katmanında yapılan analizde ilk olarak bütüncede yararlanılan Almanca ve Türkçe televizyon reklamlarının tamamında paketli ve/veya paketsiz çikolata görsellerine yer verildiği bulgulanmıştır. Elde edilen bir diğer veri ise marka yüzü olarak Almanca reklamlarda yalnızca kadın figürlerin, Türkçe reklamlarda ise Türk toplumu tarafından tanınan ünlü kadın ${ }^{14}$ ve erkeklerin ${ }^{15}$ rol almalarıdır (Karş. Şenöz-Ayata \& Atasoy, 2018, s. 14). Türkçe reklamlarda çikolataların tanıtımı için görsel kod olarak ayrıcalıklı bir sınıfın temsilcisi konumunda ünlü kiş̧ilerin kullanılması sayesinde, o kişilerin elit bir sınıfın mensubu olma özellikleri, Eti markasının çikolatalarına aktarılarak, reklamdaki ürünlerin izleyiciler için belli bir anlam taşır hale gelmesi sağlanmıştır. Çikolataları tanıtan ürün kullanıcısı konumundaki figürlerin nasıl gösterildikleri ve bulundukları ortamlar bakımından Almanca ve Türkçe reklamlar arasında bazı benzerliklere ve farklılıklara rastlanmıştır. İki dilde de reklamların kadınlar ev, kafe veya stüdyo ortamında bulunmaktadır. Almanca reklamlarda kadınlar bazen tek başına bazen de bir başka kadınla gösterilirken, Türkçe reklamların tamamında kadınlar tek başınadır. Türkçe reklamlarda belirgin bir şekilde öne çıkarılan, çikolatayı yalnız başına ve kapalı bir ortamda tüketme, "bireyin kendini çevresinden soyutlayarak çikotala yemenin bireysel bir eyleme dönüştürüldüğüne işaret etmektedir." (Atasoy, 2019a, s. 284). Bu farklılık Türkçe reklamlarda ünlü kişilerin kendileri olarak rol almalarıla ilişkilendirilebilir. Görüntü çözümlemesinden elde edilen en dikkat çekici bir başka bulgu ise figürlerin her iki dildeki reklamlarda da çikolata yedikten sonra belli bir haz duymaları ve kendilerini mutlu hissetmelerinin vurgulanmasıdır. Tanıtılan çikolataların haz ve mutluluk sağlayan özelliklerini öne çıkarmak için iki dildeki reklamların tamamında benzer kamera perspektiflerinden, renklerden, ışıklandırma tekniklerinden ve çekim ölçeklerinden yararlanıldığı belirlenmiştir. Çikolatalar ve figürler arasındaki ilişkiyi belirgin hale getirmek için ürünün temel rengi olan kahverenginin birçok sahnede kullanılmasının yanı sıra, ayrıntı veya yakın çekim ile normal ya da tepeden bakış perspektifinde, normal ışıklandırma altında görüntü alınmıştır. Bu sayede figürlerin çikolataları yerken oluşan mimikleri ve çikolataların fiziksel görüntüsü izleyicilere ayrıntılı olarak gösterilmekte ve

14 İncelenen Türkçe reklamlarda Burçin Terzioğlu, Tülin Özen ve Zerrin Tekindor rol almaktadır.

15 İncelenen Türkçe reklamlarda Selçuk Yöntem, Mete Horozoğlu ve Timuçin Esen rol almaktadır. 
onlara mutlulukla haz veren eden şeyin, reklamda görülen çikolatalar olduğu görsel olarak anlatılmaktadır. Bu anlamda hedef kitlenin ekranda izledikleri üzerinden bu çikolataları satın almak için harekete geçmeleri beklenmektedir.

Müzik katmanının çözümlemesinde Almanca reklamlarda sözlü reklam melodileriyle enstrümantal müziklerin, Türkçe reklamlarda ise yalnızca enstrümantal müziklerin kullanıldığı bulgulanmıştır (Karş. Rossi, 2010, s. 17-24). Müziklerin kullanım sıklıklarına bakıldığında Almanca reklamların çoğunda Colors of Life adlı melodiden yararlanıldığı, Türkçe reklamların tamamında ise caz ve tango türünde farklı enstrümantal müziklerin çaldığı görülmektedir. Almancada aynı melodinin birden fazla reklamda kullanılması, ilgili müziğin Ritter Sport markası ile özdeşleşerek izleyicilerin zihninde o markayı çağrıştıran bir slogana dönüşmesine yol açmaktadır (Karş. Stöckl, 2007, s. 191-195; Atasoy, 2019b, s. 323). Buna karşın Türkçe televizyon reklamlarında caz ve tango türünde müziklerin tercih edilmesi ise, hedef kitlede Eti markasına ve bu markanın çikolatalarına yönelik prestij ve kalite gibi olumlu çağrışımların yaratılmasının amaçlandığına işaret etmektedir (Karş. Bouvier \& Machin, 2013, s. 61-69). Dolayısıyla bu çalışmada çözümlenen Almanca ve Türkçe reklamlarda kullanılan müzikler arasındaki farklılık, reklamların hedef kitlelerine, markalara, tanıtılan ürünlere, olay örgüsüne ya da olay örgüsünün geçtiği ortamlara dayandırılabilir.

Ses katmanının bu çalışmada çözümlenen Almanca reklamlarda oldukça az, Türkçe reklamlarda ise belirgin biçimde fazla kullanıldığı belirlenmiştir ${ }^{16}$. Almanca ve Türkçe reklamlardaki ses kullanım yoğunlukları arasındaki bu farklılık, tanıtılan ürünlerle bağlantılı olabilir. Bütüncede incelenen Eti çikolata reklamlarında öne çıkarılan en temel ürün özelliklerinden biri, çikolataların kırılırken veya ısırılırken çıkardığı sestir. Bu özelliği vurgulamak için Türkçe reklamlarda çikolata çatırdama/kırılma sesinden yararlanılmıştır. Çikolataların kırılırken çıkardığı ses üzerinden izleyicilerin zihninde Eti çikolatalarının tazeliği ve lezzeti konusunda olumlu bir çağrışım yaratılmaya çalışılmaktadır. Almanca reklamlarda ise tanıtılan çikolataları izleyiciler için çekici hale getirmek için bazı öne çıkarılmak istenen temel bileşenlerinin (Ör: kakao, portakal, badem) ürün özelliği olarak vurgulandığı görülmektedir. Dolayısıyla Ritter Sport markasının bu çalışmada incelenen reklamlarında ses katmanının çok fazla tercih edilmemesinin nedeni de Türkçe reklamlarda olduğu gibi doğrudan tanıtılan ürünlerden kaynaklanmaktadır (Karş. Stöckl, 2007, s. 197).

16 Çözümlenen Almanca reklamların ikisinde, Türkçe reklamların ise yedisinde ses katmanı kullanılmıştır. 
İncelenen reklamlardaki katmanlararası ilişkilerde ilk olarak katmanların dağılım oranlarına bakıldığında çözümlenen Almanca reklamlarda en baskın katmanın görüntü olduğu ve bu katmandan sonraki dağılımın ikinci sırada dil, üçüncü sırada müzik ve dördüncü sırada ses katmanı olacak şeklinde devam ettiği bulgulanmıştır. Buna karşın Türkçe reklamlarda dil ve görüntü katmanlarının eşit oranda kullanıldığı saptanmıştır. Dağılım oranlarındaki bu farklıı̆̆ın çözümlenen reklamların yayın sürelerinden kaynaklandığı düşünülebilir. İncelenen Almanca reklamların yayın süreleri 10-24 saniye, Türkçe reklamların ise 19-32 saniye arasında değişmektedir. Yayın süresinin uzunluğuna bağlı olarak dil katmanının Türkçe reklamlardaki kullanım oranının Almanca reklamlarla karşılaştırıldığında daha fazla olduğu sonucuna varılabilir.

Katmanlararasılık düzleminde yapılan incelemede her iki dildeki reklamlarda da dil katmanında sözlü veya yazılı biçimde yinelenen "Schokolade/çikolata" sözcüğünün ve çikolataların bazı ürün özelliklerinin (Ör: bitter çikolata olma özelliği) ya da temel bileşenlerinin (Ör: kakao, badem) öne çıkarılmak istendiği sahnelerde görüntü katmanında parlak ya da normal ışıklandırma ile yakın çekimde normal bakış perspektifinden kadrajlanan çikolata görselleri kullanıldığı belirlenmiştir. Bunula birlikte bazı reklamlarda ilgili sahnelerde tanıtılan ürünler hakkında görsel ve dilsel olarak paylaşılan bilgileri desteklemek için çikolatayı çağrıştıran seslerden (Ör: çatırdama/kırılma sesi) yararlanıldığı görülmektedir. Aynı bilgilin görsel, dilsel ve işitsel şekilde tekrarlanması sonucunda izleyicilerin zihninde "Schokolade/çikolata" sözcüğüne karşılık olarak ekranda gördükleri reklamları veren markaların ürettiği çikolataların belirmesi beklenmektedir. Ayrıca her iki dildeki reklamlarda da tanıtılan çikolataların fiziksel özelliklerinin yanı sıra tüketildikleri ortamları ya da ürün kullanıcısı olarak gösterilen figürleri vurgulamak için arka fonda çeşitli ritimlerde ve tonlarda ilerleyen müziklerin kullanıldığı belirlenmiştir. Örneğin Almanca reklamlarda çikolataların "renkli olma özelliği" ön plandadır. Bu özelliği öne çıkarmak için görüntü katmanında renkli çikolata paketlerinden, dil katmanında renkliliği çağrıştıran "bunt/renkli" sözcüğünden ve müzik katmanında arka fonda çalan Colors of life melodisinden yararlanılmıştır. Benzer şekilde Türkçe reklamlarda vurgulanan "çikolata yemek" eylemini pekiştirmek için görüntü katmanında normal ya da yukarıdan bakış perspektifleriyle, yakın çekimde çikolata yiyen kadın ve erkek figürlerin bulunduğu görüntüler, dil katmanında "yemek" sözcüğü ve arka plandaki enstrümantal müziklerle desteklenmektedir. Dolayısıyla her iki dilde de görsel, dilsel ve işitsel katmanlar yardımıyla aynı bilgiler eş zamanlı aktarılarak reklamların izleyiciler üzerindeki etkisinin artırılmaya çalışıldığı görülmektedir. Katmanlararası ilişkiler bakımından Almanca ve Türkçe reklamların benzerlik özelliklere sahip olmaları, global pazar anlayışın günümüz 
reklamcılık faaliyetleri üzerindeki etkisiyle ilişkilendirilebilir (Karş. Buggisch, 2008, s. 113116; Opiłowski, 2015, s. 96; Atasoy, 2019b, s. 324).

\section{Sonuç}

Çikolata ve çikolata içeren ürünlerin tanıtıldığı Almanca ve Türkçe televizyon reklamlarının çok katmanlı metin yaklaşımıyla karşılaştırmalı olarak incelendiği bu çalışmada katmanların ve katmanlararası ilişkilerin ayrıntılı çözümlemesinden elde edilen sonuçlara göre iki dil arasında farklılıktan çok benzerlik bulunduğu görülmektedir. Incelemede rastlanan ilk benzerlik Almanca ve Türkçe reklamların kurgulanış biçimleri arasındadır. Her iki dildeki reklamların tümünde markalar ve hedef kitleleri arasında duygusal bir bağ oluşturulması için yoğun olarak "mutlu olmak" ile "gülümsemek" eylemlerinin yinelendiği bulgulanmıştır. Bu iki eylemin, incelenen reklamlarda kullanılan katmanlar üzerine eklemlendiği görülmektedir. Gülümsemeyi ve mutlu olmayı sağlayan unsur, reklamı yapılan çikolatalardır. Hedef kitlenin zihninde bu bağlantıyı kurabilmek için, tanıtılan çikolatalar ve onları tüketen figürler görüntü katmanında çeşitli sinematografik anlatım teknikleriyle öne çıkarılmakta ve görsel olarak iletilen bilgiler reklamlardaki diğer katmanlarla dilsel ve işitsel olarak da desteklenmektedir. Dolayısıyla her iki dildeki reklamlarda da tüketicilere çikolata yediklerinde erişecekleri haz ve mutlu olma durumu, görsel, dilsel ve işitsel olarak yinelenerek reklamları veren markaların ürettiği çikolatalarının izleyiciler üzerindeki etkisi somutlaştırılmaktadır. Böylelikle izleyicilerin reklamlarda kullanılan her katmanda stratejik biçimde tekrarlanan mutlu olmak ve gülümsemek eylemleri üzerinden ekranda gördükleri çikolataları satın almaya yönelmeleri beklenmektedir. Çözümlemeden elde edilen en ilginç bulgulardan biri, Almanca ve Türkçe reklamların hiçbirinde tanıtılan çikolatalara tat veren şeker ya da yağ gibi diğer bileşenleri hakkında herhangi bir bilgi bulunmamasıdır. İlgili bileşenler hedef kitlenin zihninde tanıtımı yapılan çikolatalara yönelik olumsuz bir çağrışım yaratabileceği için her iki dilde de bu unsurlara yönelik bilgi vermekten kaçınıldığı görülmektedir.

Yapılan ayrıntılı analizde bütüncedeki Almanca ve Türkçe reklamlarda kullanılan bazı katmanlar ve dağılım oranları açısından az sayıda farklılığa da rastlanmıştır. Bu farklıklar özellikle müzik ve ses kullanımı ile katmanların kullanım oranlarında karşımıza çıkmaktadır. Söz konusu farklar, ilk olarak reklamların yayın süreleriyle ilişkilendirilebilir. Almanca reklamlara ayrılan sürenin Türkçe reklamlara göre oldukça kısa olması, iki dilde benzer katmanların aynı oranda kullanımını zorlaştırmaktadır. Bir başka neden olarak markaların 
değerleri düşünülebilir. Ritter Sport ${ }^{17}$, Türk çikolata üreticisi Eti'18 ile karşılaştıııldığında çok daha eski ve daha küresel bir markadır. Bu anlamda Almanca reklamlarda kalıplaşmış ve markaya özgü sayılabilecek bazı temel unsurları görsel, dilsel ve işitsel katmanlar üzerinden kullandığı söylenebilir. Bununla birlikte reklamlarda tanıtılan ürünlerin türleri de farklılığa yol açan unsurlardan biri olarak görülebilir. Türkçe reklamlardaki ürünlerin bitter olma özelliği, Almanca reklamlarda ise renkli olma özelliği vurgulanmaktadır. Bu özellikleri öne çıkarmak için her iki dilde de katmanların kullanım yoğunluğu ve dağılım oranları arasında farklı stratejilerin benimsendiği sonucuna varılabilir.

$\mathrm{Bu}$ çalışmada yararlanılan bütüncenin tamamının çikolata ve/veya çikolatalı ürün içeren televizyon reklamlarından oluşması, inceleme sonucunda bu reklamlar arasında çok sayıda ortak özelliğe rastlanmasına yol açan başlıca nedenlerden biridir. Bunun yanı sıra günümüz küresel pazar şartlarında reklamların bazı temel özellikler bakımından giderek birbirine yaklaşmaya başlamış olmalarının da bu benzerlikler üzerinde etkisi olduğu düşünülebilir. Çözümlenen reklamlarda bulunan ortak özellikler, globalleşen satış pazarı anlayışının etkisiyle farklı dillerde üretilmiş olsalar bile reklamlar arasındaki başkalaşmanın, dile ya da kültüre özgü olma durumunun ortadan kalkmaya başladığına ve mümkün olan en geniş kitleye ulaşabilmek için belli ölçüde benzer özelliklere sahip olmaları gerektiğine işaret etmektedir.

Hakem Değerlendirmesi: Dış bağımsız.

Çıkar Çatışması: Yazar çıkar çatışması bildirmemiştir.

Finansal Destek: Yazar bu çalışma için finansal destek almadığını beyan etmiştir.

Peer-review: Externally peer-reviewed.

Conflict of Interest: The author has no conflict of interest to declare.

Grant Support: The author declared that this study has received no financial support.

\section{Kaynakça}

Atasoy, İ. (2016). Multimodale Texte im Vergleich: Eine kontrastive interlinguale Analyse deutscher, englischer, italienischer und türkischer Fernsehwerbungen, Temeswarer Beiträge zur Germanistik Band: 13, 91-101.

Atasoy, İ. (2017). Dilbilimsel ve Göstergebilimsel Yaklaşımla Almanca, İtalyanca ve Türkçe Dergi Reklamlarında Çok Katmanlılık Analizi. International Journal of Language Academy Vol. 5/8, 316-330.

17 Ritter Sport markasının ürünleri 100 farklı ülkede satılmaktadır. Bilgi için Bkz.: https://www.ritter-sport.de/ en/Family-business-values/facts_figures.html. Son erişim tarihi 25.05.2019.

18 Eti markasının ürünleri Türkiye dışında Romanya ve Polonya'da satılmaktadır. Bilgi için Bkz.: https://www. etiinternational.com. Son erişim tarihi 25.05.2019. 
Atasoy, İ. (2019a). Almanca, Ingilizce ve Türkçe Reklam Filmlerinin Dilbilimsel Incelemesi. (Doktora Tezi). İstanbul Üniversitesi Sosyal Bilimler Enstitüsü, İstanbul.

Atasoy, İ. (2019b). Multimodalität in Fernsehwerbungen: Kontrastive Fallanalyse deutscher, italienischer und spanischer TV-Spots am Beispiel der Marke Knorr, Temeswarer Beiträge zur Germanistik Band: 16, 305-327.

Bouvier, G \& Machin, D. (2013). How advertisers use sound and music to communicate specific ideas, attitudes and identities? A multimodal, critical discourse approach. In Pennock-Speck, B \& Del Sazrubio, M (Ed.), The Multimodal Analysis of Television Commercials, (pp. 61-91). Publidisa: Valencia.

Brandt, W. (1973). Die Sprache der Wirtschaftswerbung. Ein operationelles Modell zur Analyse und Interpretation von Werbungen in Deutschunterricht, Germanistische Linguistik, 1-2.

Brinker, K. (1997). Linguistische Textanalyse, Eine Einführung in Grundbegriffe und Methoden. Berlin: Eric Schmidt Verlag.

Buggisch, B. (2008). Nahrungsmittelwerbung und Kulturspezifik. Ein interkultureller Vergleich, In Held, G. \& Bemdel, S. (Hrsg.), Werbung Grenzlos: Multimodale Werbetexte im interkulturellen Vergleich, (S. 95-124). Frankfurt am Main: Peter Lang Verlag.

Hennecke, A. (1999). 1999: Im Osten Nichts Neues? Eine pragmalinguistisch-semiotische Analyse ausgewählter Werbeanzeigen für Ostprodukte im Zeitraum 1993 bis 1998. Frankfurt am Main: Lang Verlag.

Hoffmann, E. (2014). Bierwerbung in Deutschland: Eine Analyse der Werbesprache. Hamburg: Igel RWS Verlag. Janich, N. (2010). Werbesprache ein Arbeitsbuch. Tübingen: Narr Verlag.

Klug, M. \& Stöckl, H. (2015). Sprache im multimodalen Kontext. In Felder, E. \& Gardt, A. (Hrsg), Handbuch Sprache und Wissen, (S. 242-266). Berlin: De Gruyter.

Kress, G. (2010). Multimodality: A Social Semiotic Approach to Contemporary Communication. New York: Routhledge.

Kunt, A. (2007). Stellenwert der Familie in den türkischen und deustchen Werbetexten: Ein Beitrag zur Lexikologie, Semantik und Syntax. (Yüksek Lisans Tezi). Hacettepe Üniversitesi.

Opiłowski, R. (2015). Ein kontrastiver Blick auf die Multimodalität in der deutschen und polnischen Pressewerbung. Eine Fallstudie. Tekst i Dyskurs -Text und Diskurs, 91-101.

Şenöz-Ayata, C. \& Atasoy, İ. (2018). Ein interkultureller Blick auf Multimodalität in ausgewählten deutschen, angloamerikanischen, italienischen und türkischen Kosmetikwerbeanzeigen, Alman Dili ve Edebiyatı Dergisi - Studien zur deutschen Sprache und Literatur, 41, 1-23.

Mahovský, M. (2007). Sprachliche Ausdrucksmittel der Werbung in der Lebensmittelindustrie. (Yüksek Lisans Tezi). Masaryk Üniversitesi.

Manca, C. (2012). Geschlechterwissen in der TV-Werbung Fallanalyse eines deutschen Nahrungsmittel- Werbespots am Beispiel der Marke Knorr. (Yüksek Lisans Tezi). Viyana Üniversitesi.

Polajnar, J. (2005). Adressierungsstrategien in Kinderwerbespots. Zur Ansprache von Kindern und Eltern im Fernsehen. Wiesbaden: Springer Verlag.

Romanenko, E. (2014). Linguistic Analysis of Online Advertising in English. (Doktora Tezi). Charles Üniversitesi. 
Rossi, C. (2010). Argumentationsstrategien in den Werbespots von "Kinderschokolade". (Yüksek Lisans Tezi). Ferrara Üniversitesi.

Sowinski, B. (1998). Werbung (Grundlagen der Medienkommunikation Band 4). Tübingen: Nimeyer.

Stöckl, H. (2004a). Werbekommunikation - Linguistische Analyse und Textoptimierung. In Knapp, K. et al. (Hg.), Angewandte Linguistik-Ein Lehrbuch, (S. 233-254). Tübingen: UTB Francke.

Stöckl, H. (2004b). In between modes. Language and Image in Printed Media, In Kaltenbacher, M. \& Charles, C \& Ventola, E. (Eds.), Perspectives on Multimodality, (pp. 9-30). Amsterdam/Philadelphia: John Benjamins Publishing Company.

Stöckl, H. (2006). Zeichen, Text und Sinn - Theorie und Praxis der multimodalen Textanalyse. In Eckkrammer, E. M. \& Held, G. (Hrsg.), Textsemiotik. Studien zu multimodalen Medientexten (= Sprache im Kontext), (S. 11-36). Frankfurt am Main: Lang Verlag.

Stöckl, H. (2007). Hörfunkwerbung - Kino für das Ohr. Medienspezifika, Kodeverknüpfungen und Textmuster einer vernachlässigten Werbeform. In Roth, K. S. \& Spitzmüller, J (Hrsg.) Textdesign und Textwirkung in der massenmedialen Kommunikation, (S. 177-202). Konstanz: UVK.

Stöckl, H. (2011). Multimodale Werbekommunikation - Theorie und Praxis. ZfAL Zeitschrift für Angewandte Linguistik, 5-32.

Stöckl, H. \& Schneider, J. G. (2011). Medientheorien und Multimodalität - Zur Einführung. In Schneider, J.G. \& Stöckl, H. (Hrsg.), Medientheorien und Multimodalität. Ein TV-Werbespot - Sieben methodische Beschreibungsansätze, (S. 10-38). Köln: Herbert von Halem.

Stöckl, H. (2012). Werbekommunikation semiotisch. In Janich, N. (Hg.), Handbuch Werbekommunikation. Sprachwissenschaftliche und interdisziplinäre Zugänge, (S. 243-262). Tübingen: UTB Francke.

Van Leeuwen, T. (2005). Introducing Social Semiotics. New York: Routledge.

Wildfeuer, J. (2012). Intersemiosis in Film: Towards a New Organisation of Semiotic Resources in Multimodal Filmic Text. In Sigrid, N. (Ed), Multimodal Communication 1 (3), (pp. 276-304). Auckland: De Gruyter.

Wyss, E. (2011). Erzählen in bewegten Werbebildern. Narrative Muster und Logiken des Werbens zwischen Story und Produkt. In Diekmannshenke, H. \& Klemm, M. \& Stöckl, H. (Hrsg.), Bildlinugistik, (S. 277-302). Berlin: Erich Schmidt Verlag.

Yılmaz, E. (2004). Medyatik Dil Alanları: Reklamcılık Dili Üzerine Metin Dil Bilimsel Bir İnceleme. Türk Dili, Sayı: 600.

\section{Bütünce}

\section{Almanca Televizyon Reklamları}

Ritter Sport Wintersorten, 2010: https://www.youtube.com/watch?v=E6luNyJ4lsA.

Ritter Sport Espresso, 2010: https://www.youtube.com/watch?v=KROWDziljsU.

Ritter Sport Weiss und Crisp, 2011: https://www.youtube.com/watch?v=j-TJKr4AJ7I.

Ritter Sport Vanille Mousse, 2012: https://vimeo.com/86180965.

Ritter Sport Knackige Schokolade, 2012: https://www.youtube.com/watch?v=_Z3tSojv8_o. 
Ritter Sport Schokowürfel, 2013: https://www.youtube.com/watch?v=xNz86Dczbyo. Ritter Sport Weihnachtsfreude, 2014: https://www.youtube.com/watch?v=ICrKSOhPtwc. Ritter Sport Sommersorten, 2014: https://www.youtube.com/watch?v=3G-6d-Malag. Ritter Sport Sorte des Jahres, 2015: Honig-Salz-Mandel https://www.youtube.com/watch?v=LqOLi9Bo300. Ritter Sport Wintersorten, 2015: https://www.youtube.com/watch?v=OZHf3OUIWil.

\section{Türkçe Televizyon Reklamları}

Selçuk Yöntem Eti Karam Bitter, 2011: https://www.youtube.com/watch?v=eK_GaXpLnYo. Acılığı Azaltılmış Eti Karam Bitter, 2011: https://www.youtube.com/watch?v=FxXrhYBX2pA. Zerrin Tekindor Eti Karam Bitter, 2012: https://www.youtube.com/watch?v=kWwWWueFD-g. Timuçin Esen Eti Browni Intense, 2012: https://www.youtube.com/watch?v=s1HFMxweF98. Mete Horozoğlu Eti Browni Intense, 2014: https://www.youtube.com/watch?v=ubsu0t6YGhE. Eti Browni Intense Serin Lezzet, 2014: https://www.youtube.com/watch?v=pkWSSHM2Mxg. Burçin Terzioğlu Eti Browni Intense, 2015: https://www.youtube.com/watch?v=bp4RiQlv2UQ. Selçuk Yöntem Eti Karam Bitter, 2015: https://www.youtube.com/watch?v=fKCO-SDCpJs. Eti Keyfince, 2016: https://www.youtube.com/watch?v=_zt9emLSn_g. Tülin Özen Eti Browni Intense, 2016: https://www.youtube.com/watch?v=nTzPT6fVJo8. 